\title{
The Sarmatian/Pannonian boundary at the western margin of the Vienna Basin (City of Vienna, Austria)
}

\author{
Mathias HARZHAUSER ${ }^{\left.1{ }^{*}\right)}$, Oleg MANDIC ${ }^{1)}$, Matthias KRANNER ${ }^{1)}$, Petra LUKENEDER ${ }^{11}$, Andrea K. KERN ${ }^{22}$, Martin Gross ${ }^{3)}$, \\ Giorgio (ARNEVALE ${ }^{4)} \&$ Christine JAWECKI ${ }^{5}$ \\ 1) Geological-Paleontological Department, Natural History Museum, Vienna, Burgring 7, 1010 Vienna, Austria; mathias.harzhauser@nhm-wien.ac.at; oleg. \\ mandic@nhm-wien.ac.at; petra.lukeneder@gmx.at; \\ 2) Department of Sedimentary and Environmental Geology, University of São Paulo, Rua do Lago 562, São Paulo 05508-080, Brazil; annkkern@usp.br; \\ 3) Universalmuseum Joanneum, Department for Geology \& Palaeontology, Weinzöttlstraße 16, 8045 Graz, Austria; martin.gross@museum-joanneum.at; \\ 4) Università degli Studi di Torino, Dipartimento di Scienze della Terra, Via Valperga Caluso, 35, 10125 Torino, Italy; giorgio.carnevale@unito.it; \\ 5) Magistratsabteilung 29, Brückenbau und Grundbau, Wilhelminenstraße 93, 1160 Vienna, Austria; christine.jawecki@wien.gv.at; \\ *) Corresponding author: mathias.harzhauser@nhm-wien.ac.at
}

\section{U⿺辶了:}

KEYWORDS Vienna Basin; Miocene; Paratethys Sea; Lake Pannon; authigenic pyrite

\begin{abstract}
Sarmatian and Pannonian cores, drilled at the western margin of the Vienna Basin in the City of Vienna, reveal a complex succession of marine and lacustrine depositional environments during the middle to late Miocene transition. Two Sarmatian and two Pannonian transgressive-regressive sequences were studied in detail. Identical successions of benthic faunal assemblages and similar patterns in magnetic susceptibility logs characterise these sequences. This allows a correlation of the boreholes over a distance of $\sim 3.5 \mathrm{~km}$ across one of the major marginal faults of the Vienna Basin. Biostratigraphic data, combined with rough estimates of sedimentation rates, reveal large gaps between these sequences, suggesting that only major transgressions reached this marginal area. In particular, during the Sarmatian-Pannonian transition, the basin margin completely emerged and turned into a terrestrial setting for at least $600 \mathrm{ka}$.
\end{abstract}

\section{Introduction}

The Sarmatian/Pannonian boundary around $11.6 \mathrm{Ma}$ coincided with the largest biotic crisis in the Central Paratethys Sea resulting from its geographic isolation and transition into a lacustrine setting (Harzhauser and Piller, 2007). A plethora of papers deals with the stratigraphy and ecology of the Sarmatian Sea and Lake Pannon around this critical phase (e.g. Magyar et al., 1999; Harzhauser and Piller, 2004; Sztanó et al., 2005; Vasiliev et al., 2010; Lirer et al., 2009; Filipescu et al., 2011; ter Borgh et al., 2013; Neubauer et al., 2016). Due to the limited extent of Lake Pannon during its initial phase, continuous sedimentary records spanning the Sarmatian/Pannonian transition are a priori restricted to basinal settings, whereas the marginal areas have been exposed to erosion (see maps in Magyar et al., 1999). While much effort has been previously and is being currently made to identify continuous records, the ubiquitous gaps have attracted no attention so far. Defining the duration of these phases of erosion and non-deposition, however, is crucial to describe basin development on a regional scale, leading to a better understanding of the palaeo-topography and improvement of the temporal resolution of the regional tectonic history.

Herein, we focus on a series of rises in sea/lake levels and depositional gaps recorded by siliciclastic-dominated successions along the western margin of the Vienna Basin within the territory of the City of Vienna. First observations on the geological situation of the Sarmatian and Pannonian strata in Vienna were made in the late $19^{\text {th }}$ and early $20^{\text {th }}$ centuries, when numerous outcrops existed in the city (e.g. Karrer, 1877; Schaffer, 1906). Since these outcrops soon disappeared under buildings, Tauber (1939a, b) was among the last geologists who discussed the Sarmatian/Pannonian boundary in Vienna based on surface outcrops. At that time, most geologists postulated a so-called transitional zone, in which Sarmatian and Pannonian species co-occur, because reworking of Sarmatian shells was neglected due to their oftenexcellent preservation (Tauber, 1939a, b). Since then, the Sarmatian and Pannonian successions along the western margin of the Vienna Basin received little attention, and the official geological maps show only very general subdivisions into "Sarmatian" and "Pannonian" for Vienna (Fuchs, 1985; Schnabel et al., 2002). Now, new information has become available during the planning stage of the construction of new underground networks, allowing a precise description of Sarmatian and Pannonian depositional environments, biostratigraphy and depositional gaps.

\section{Geographical and geological setting}

In 2014, the municipal department MA 29 drilled several boreholes within the City of Vienna (Austria) during the planning phase of subway constructions. Herein, we focus on two groups of boreholes: the first group comprises drillings in the $9^{\text {th }}, 17^{\text {th }}$ and $18^{\text {th }}$ districts, forming a west-southwest WSW-ENE transect close to the western margin of the Vienna Basin 
(rotary kelly bushing RKB 5320, RKB 5300, RKB 5260; Fig. 1). Tectonically, the boreholes are situated at the basin margin, west of the Bisamberg and Leopoldsdorf faults (Fig. 1). The second group of drillings is situated in the $5^{\text {th }}$ and $6^{\text {th }}$ districts and roughly forms a northwest NNW-southeast SSE transect crossing the Wien river valley (RKB 7260, RKB 7280, RKB 7300, RKB 7320; Fig. 1). Tectonically, these drillings are situated within the Vösendorf Basin, a small, roughly southwest SSW-northeast NNE trending depression separating the basin margin from the Mödling Block to the south and southeast and the Oberlaa High to the east (Fig. 1; Kröll and Wessely, 1993; Wessely, 2006).

The Sarmatian part of the RKB cores is part of the upper Sarmatian Skalica Formation as defined by Elečko and Vass (2001). This formation is widespread throughout the Vienna Basin and the adjacent Eisenstadt-Sopron Basin. Elečko and Vass (2001) named the formation after the town Skalica in the Slovak Republic. Its type section is the Vrádište-2 well (154-5 m) at Holíč in the Slovak Republic. Informal names for this formation used for deposits within the area of Vienna are "Cerithienschichten" (Beds with cerithiids) (Suess, 1866) and "Atzgersdorfer Schichten" (Beds of Atzgersdorf) (Brix, 1988). Outcrops of the Skalica Fm. usually expose a variety of lithologies, ranging from marl and silt to sandstone and gravel, as well as mixed siliciclastic-carbonatic deposits, such as oolites and rock-forming coquinas (= Beds of Atzgersdorf"). The predominantly pelitic deposits of the RKB cores represent a more distal, basinal facies of the Skalica Fm.

The pelitic Pannonian units of the RKB cores represent lower parts of the Bzenec Formation, as defined by Čtyroký (2000) and Harzhauser et al. (2004). Čtyroký (2000) defined this formation for the lacustrine deposits of Lake Pannon in the Czech part of the Vienna Basin. The type section comprises the Kyj- 1 and Kyj-2 wells in the lignite mine Pokrok, near the village Žeravice at Kyjov in the Czech Republic. Informal names for this formation used for deposits within the area of Vienna are "Congerienschichten" (Beds with Congeria), "Brunner Schichten" (Beds of Brunn) (Krenmayr and Schnabel, 2002) and "Inzersdorfer Tegel" (Clay of Inzersdorf) (Brix, 1988). No outcrops of the lower part of the Bzenec Fm. are currently exposed near or in Vienna. The famous outcrops at Hennersdorf, south of Vienna, represent the upper parts of the Bzenec Fm (Kern et al., 2012a, 2012b).

\section{Materials and methods}

All boreholes reached a final depth of $60 \mathrm{~m}$ and were fully cored (Fig. 2). The cores are stored in wooden boxes of 1-m length and are available for sampling in the core shed of the municipal department MA 29. The boreholes
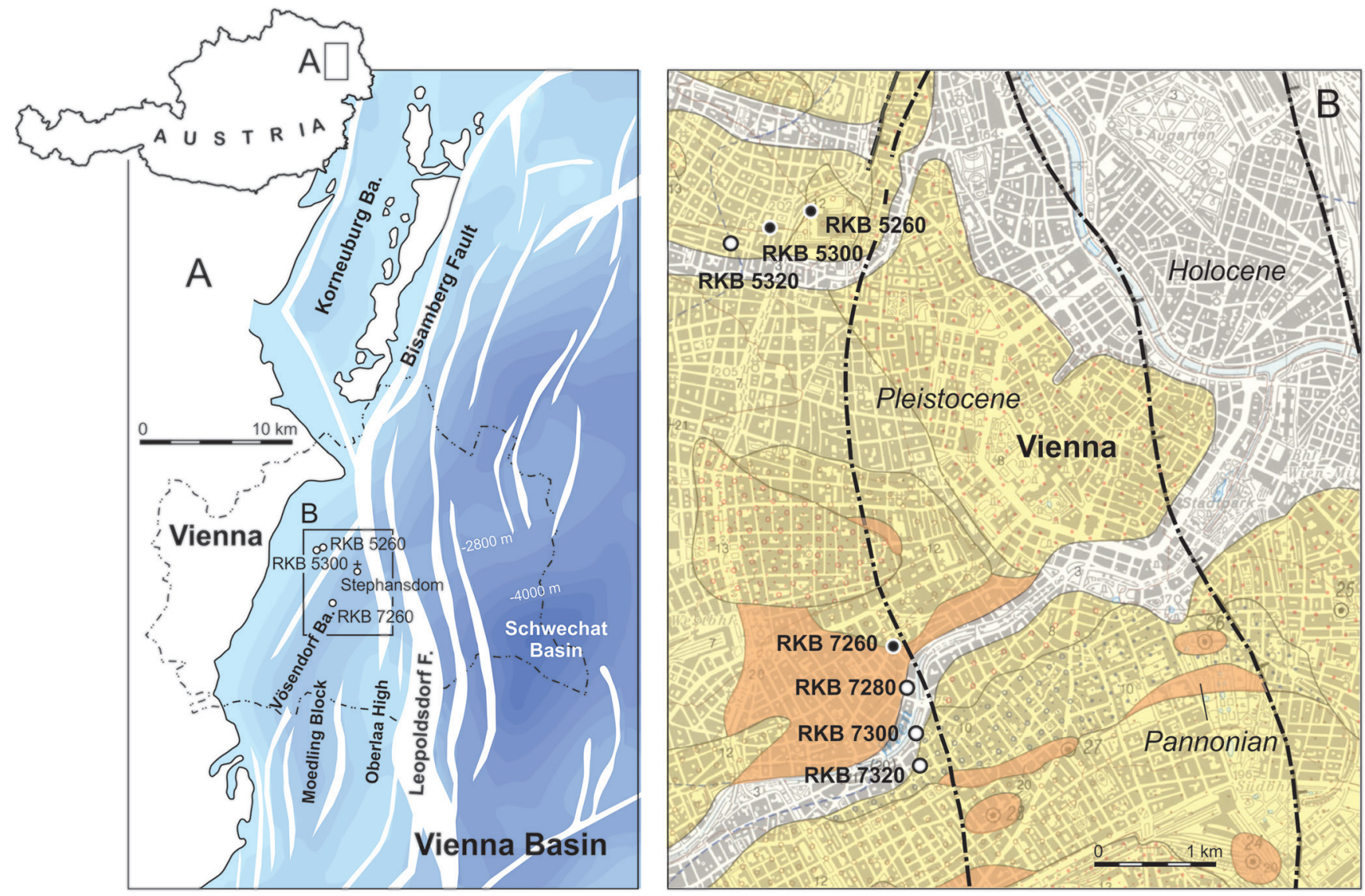

Figure 1: Geologic setting of the investigation area. A: Structural map of the pre-Neogene basement of the Vienna Basin (VB) after Kröll and Wessely (1993) and Wessely (2006), with the position of the boreholes at the western margin of the VB and in the Vösendorf Basin. B: Position of the boreholes plotted on the geological map of Fuchs (1985), black lines represent faults. 

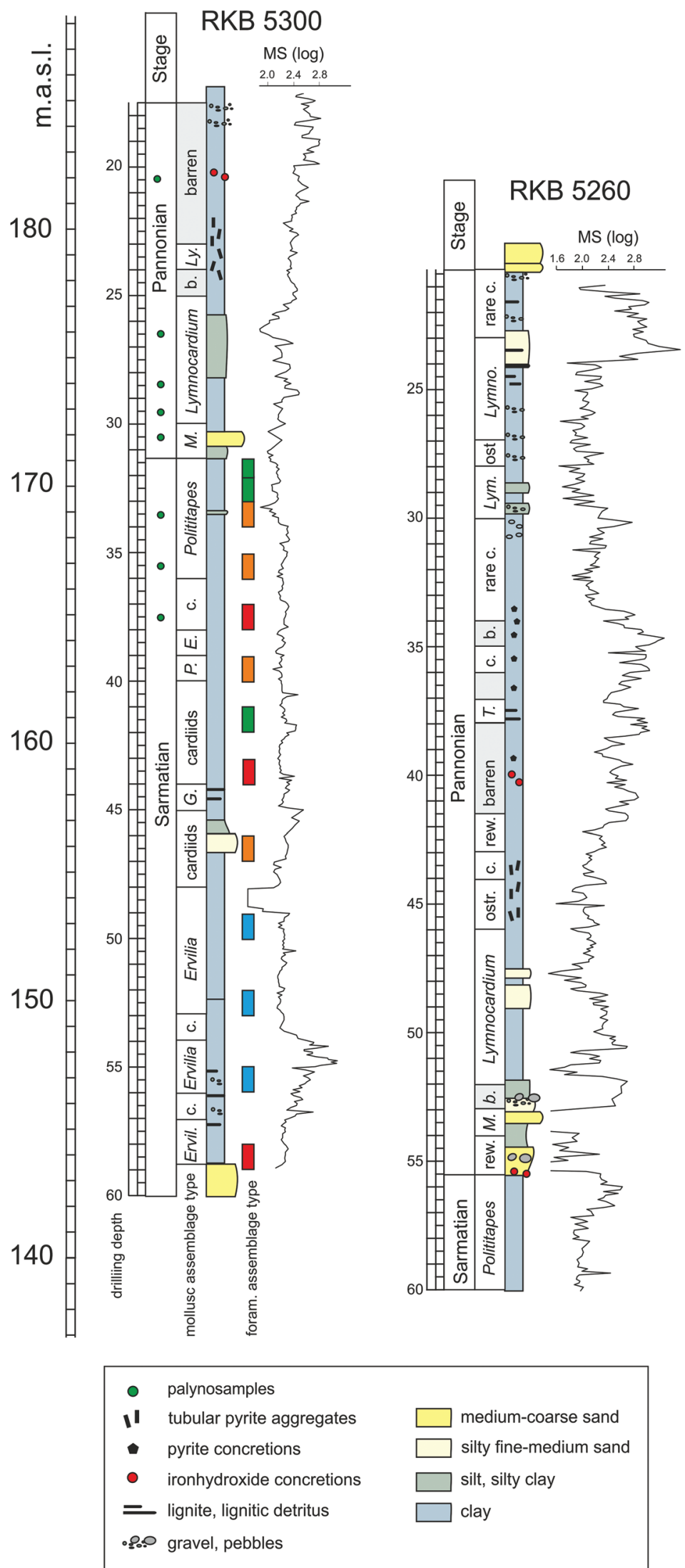

170

160

150

140

130

$$
50
$$

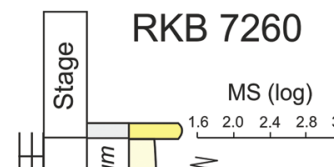
z

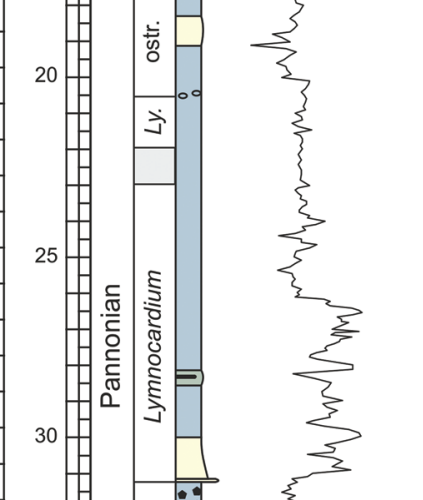

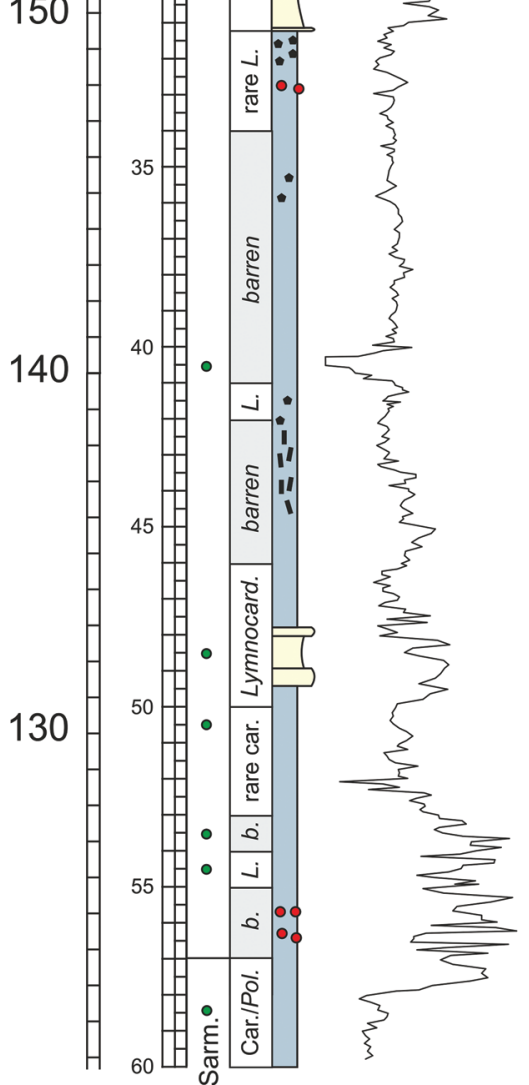

Figure 2: Simplified lithological logs of the cores; position in metres above sea level. Sample numbers in text correspond to core metres. Dominant mollusc and foraminiferal assemblage types are indicated next to the litho-log, along with magnetic susceptibility values. Abbreviations: b. = barren of macrofossils, rew. = reworked Sarmatian shells, ostr. = ostracod mass occurrences, C. = cardiids, E. = Ervilia dissita, G. = Granulolabium bicinctum, L. = Lymnocardiidae, M. = Melanopsis pseudonarzolina, P. = Polititapes tricuspis, $\mathrm{T}$. = Theodoxus sp.; the colour code of the foraminiferal assemblages follows the colour code of the clusters in Fig. 6. 
penetrated the Sarmatian/Pannonian boundary, and most of them drilled through a Holocene/anthropocene cover of $\sim 6-20 \mathrm{~m}$ thickness. In an internal report of the municipal department MA 29, a preliminary biostratigraphic analysis tried to define the Sarmatian/Pannonian boundary in the cores (Maslo, 2015). Sedimentology and sedimentary structures were documented by the drilling company; these data were made available to us by the municipal department MA 29. Within this project, three cores were sampled to define the Sarmatian/Pannonian boundary in more detail based on palaeontological data:

- RKB 7260 (Margaretenstraße 108, 1050 Vienna; $\mathrm{N} 48.196074^{\circ}, \mathrm{E} 16.352512^{\circ}$ )

- RKB 5300 (Theresiengasse 34, 1080 Vienna; $\left.\mathrm{N} 48.220493^{\circ}, \mathrm{E} 16.341733^{\circ}\right)$

- RKB 5260 (rescue parking place in the Vienna General Hospital, AKH, 1090 Vienna; N 48.221543', E $16.345415^{\circ}$ )

The distance between RKB 5300 and 5260 is 300 m, whereas the southern borehole RKB 7260 is at a distance of $\sim 3.5 \mathrm{~km}$ (Fig. 1). Samples were taken from the middle of each core meter, excluding Holocene and anthropocene units. Each sample was treated with diluted $\mathrm{H}_{2} \mathrm{O}_{2}$ for several hours and, afterwards, washed with tap water and sieved through a set of standard sieves. Foraminifers and ostracods were picked and counted (Appendix 1). Additionally, gastropods, bivalves, serpulids and otoliths were collected for supplementary palaeo-ecological and biostratigraphical information. Foraminifers were quantitatively analysed, whereas only presence/absence was evaluated for all other taxa (Appendix 2).

Palynological samples were selected from cores RKB 5300 and RKB 7260 and processed at the Austrian Geological Survey. Each sample $(10 \mathrm{~g})$ was processed following the steps of Faegri and Iversen (1989) by using concentrated $\mathrm{HCl}$ and hydrofluoric acid to dissolve all carbonates and silicates. Furthermore, all samples were sieved through a $6 \mu \mathrm{m}$ nylon sieve to remove small organic matter before non-permanent slides were prepared for counting under the light microscope. From each sample, 300 pollen grains were identified (excluding the dominant Pinus spp.) using several atlases, such as Klaus (1984), Planderova (1990) and Stuchlick et al. (2001; 2002; 2009; 2014). Climatic analysis followed all suggestions and techniques of the Co-existence Approach (Mosbrugger and Utescher, 1997; Utescher et al., 2014). Based on the nearest-living-relative principle, this method assumes a climatic range of a fossil plant taxon based on the climatic range of its nearest living relative. The climatic ranges of each taxon from the fossil assemblage are overlain to define a climatic interval in which all of the nearest living relatives could co-exist. If such a co-existence interval is present, the climatic range represents the hypothetical climate of the past. In total, seven climatic parameters for temperature and rainfall were reconstructed, which are the mean annual temperature (MAT), coldest month temperature (CMT) and warmest month temperature (WMT), as well as mean annual precipitation (MAP), precipitation of the wettest month (MPwet), precipitation of the driest month (MPdry) and precipitation of the warmest month (MPwarm) (Appendix 3).

During the sampling process, measurements of magnetic susceptibility (MS) were taken on site using an "SM$20^{\prime \prime}$ magnetic susceptibility meter with a sensitivity of $10^{-3} \mathrm{SI}$ units (GF Instruments, Brno, Czech Republic). The measurements are presented as log-transformed values for better visualization of the patterns (Fig. 2). These measurements were done to detect potential similarities in wire-log patterns for core correlations. Herein, we are not interpreting the MS values in terms of sedimentary environments; for a discussion on the interpretation of MS values in Lake Pannon deposits, see Kern et al. (2012a).

The diversity indices 'Dominance' and 'Equitability' were computed based on the specimen counts using the software PAST (Hammer et al., 2001). Dominance ranges from zero (all taxa are equally present) to one (one taxon dominates the community completely), and equitability measures the evenness with which specimens are divided among the taxa present (Harmer and Harper, 2006; Hammer et al., 2001).

\section{Results}

\subsection{Macrofossils and lithology}

Apart from barren intervals in the Pannonian cores, molluscs occur throughout the cores as scattered shells and rarely as thin coquina layers. Due to sediment compaction, the coring technique and the washing procedure, bivalve shells - and especially the fragile cardiid shells are generally strongly fragmented.

RKB 5300 starts with a unit ( 1-m thickness) of medium sand with gravel intercalations and mollusc coquinas. Upsection follows a rather uniform 12-m-thick unit of greenish-grey clay and silt, with dispersed lignitic plant debris and gravel stringers in the basal part. This part of RKB 5300 (samples 5300-59/58 to 530048/47) is characterised by Ervilia-cardiid assemblages with large numbers of Ervilia dissita, Inaequicostata politioanei and Chartocardium carasi, along with Musculus sarmaticus and Obsoletiforma vindobonense (Fig. 3). Gastropoda, such as "Valvata" soceni wiesenensis, and Hydrobiidae are most frequent in the lower part of this unit. Similarly, tubes of the polychaete Spirorbis bilineatus are moderately frequent, present only in samples RKB 5300-59/58 and 5300-57/56 (Fig. 3). Otoliths of the small-sized cod Paratrisopterus caspius are also only found in this basal part (RKB 5300-58/57) (Fig. 3). A sandy and silty unit occurs from 45.9 to 46.6 $\mathrm{m}$, followed by lignitic silt/clay up to $44 \mathrm{~m}$; in the corresponding samples RKB 5300-47/46 to 5300-45/44, Ervilia declines and cardiids predominate the assemblages. Among the gastropods, Granulolabium bicinctum and Acteocina lajonkaireana become frequent. Cardiid-dominated assemblages with low amounts of gastropods such as Retusa sp. and Acteocina lajonkaireana appear again in the following clay/silt interval up to 


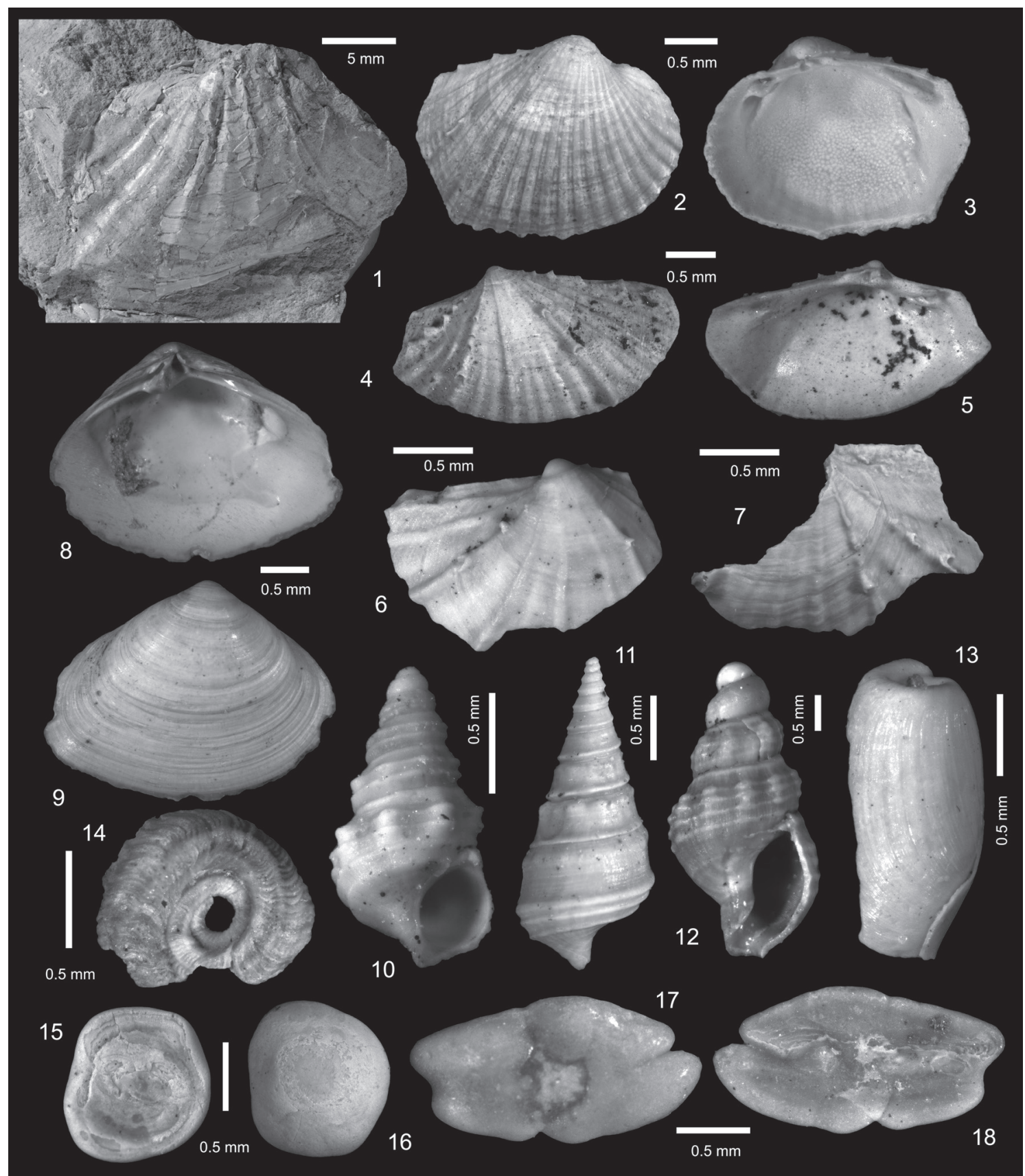

Figure 3: Sarmatian macrofossils; bivalves: 1: Chartocardium carasi (Jekelius, 1944) (RKB 5300-51/50), 2-3: Obsoletiforma jekeliusi (Papp, 1954) (RKB 5260-58/57), 4-5: Inaequicostata politioanei (Jekelius, 1944) (RKB 5300-47/46); 6-7: Chartocardium carasi (Jekelius, 1944) (RKB 7260-58/57), 8-9: Ervilia dissita (Eichwald, 1830) (RKB 5300-51/50); gastropods: 10: Cerithium rubiginosum (Eichwald, 1830) (RKB 5300-46/45), 11: Granulolabium bicinctum (Brocchi, 1814) (RKB 5300-47/46), 12: Akburunella cf. triformis (Kolesnikov, 1932) (RKB 5300-40/39), 13: Retusa sp. (RKB 5300-34/33); polychaetes: 14:Spirorbis bilineatus (Schmidt, 1951) (RKB 5300-57/56); otoliths: 15-16: Hesperichthys reductus (Schwarzhans et al., 2017) (RKB 5300-38/37), 17-18: Paratrisopterus caspius (Bogatshov, 1929) (RKB 5300-59/58).

sample RKB 5300-37/36. Numerous bone fragments and scales accompany otoliths of the Sarmatian sand goby Hesperichthys reductus in RKB 5300-38/37. Although no significant lithological change occurs, the assemblages shift distinctly towards Polititapes tricuspis-dominated assemblages from sample RKB 5300-36/35 to 5300$32 / 31$. Gastropods are mainly represented by Acteocina lajonkaireana and Hydrobiidae, along with a single occurrence of Melanopsis impressa, in RKB 5300-33/32. A sand bed with gravel is intercalated from 30.3 to 31.3 $\mathrm{m}$; it is rich in fragmented and partly abraded shells of
Polititapes tricuspis and Obsoletiforma vindobonensis; shells of Melanopsis pseudonarzolina are well preserved. The upper part of the core up to $16.6 \mathrm{~m}$ comprises clay and silty clay, interrupted only by a fine sand/silt unit from 25.7 to $28.1 \mathrm{~m}$. Shells of Lymnocardium timisense and $L$. pseudoobsoletum are characteristic in samples RKB 5300-29/28 to 5300-26/25 and 5300-24/23. Sample RKB 5300-25/24 and all samples above RKB 5300-24/23 are barren of molluscs (but contain ostracods). Small pyrite tubes are abundant in the interval from 22 to $25 \mathrm{~m}$. The uppermost $\sim 17 \mathrm{~m}$ of the core drilled 
Holocene/anthropocene sand and gravel and are not investigated herein.

RKB 5260: The basal $5 \mathrm{~m}$ comprise silty clay with rich mollusc faunas; Polititapes tricuspis predominates the assemblages along with cardiids, such as Obsoletiforma vindobonensis. A sandy unit with coarse gravel and pebbles passing upsection into fine sand with silt intercalations occurs from 55.5 to 52.5 m. Abraded Sarmatian molluscs and iron oxide concretions are frequently found in the base of this interval (RKB 5260-56/55); other samples are barren of molluscs, except for rare Melanopsis pseudonarzolina in RKB 5260-54/53 (Fig. 4). Upsection follows a rather uniform succession of clay and silty clay; fine sand intercalations occur at 49.0 to $47.5 \mathrm{~m}, 29.8$ to $28.6 \mathrm{~m}$ and 24.0 to $22.7 \mathrm{~m}$. Lymnocardiid-dominated mollusc assemblages with rare dreissenids characterise samples RKB $5260-52 / 51$ to $5260-47 / 46$. Pyrite tubes are very frequent in samples RKB 5260-46/45 to 5260-44/43, accompanied by mass occurrences of ostracods; molluscs are subordinate in this interval. The following samples are either barren or contain only few autochthonous lymnocardiids and/or reworked Sarmatian shells. Lignitic detritus and shell fragments of Theodoxus sp. appear in RKB 5260$38 / 37$. Upsection follows an interval with rare lymnocardiids and partly barren samples; spherical pyrite concretions occur scattered between RKB 5260-37/36 and RKB 5260-34/33. At RKB 5260-30/29, rich limnocardiid assemblages reappear. These samples bear diverse mollusc assemblages, with Socenia soceni, Goniochilus haidingeri (Fig. 4) and juvenile Melanopsis of the Melanopsis fossilis flock (RKB 5260-29/28). The diversity declines distinctly in the uppermost samples (RKB 5260-23/22 to 5260-21/20); in addition, lignitic detritus becomes frequent above 25

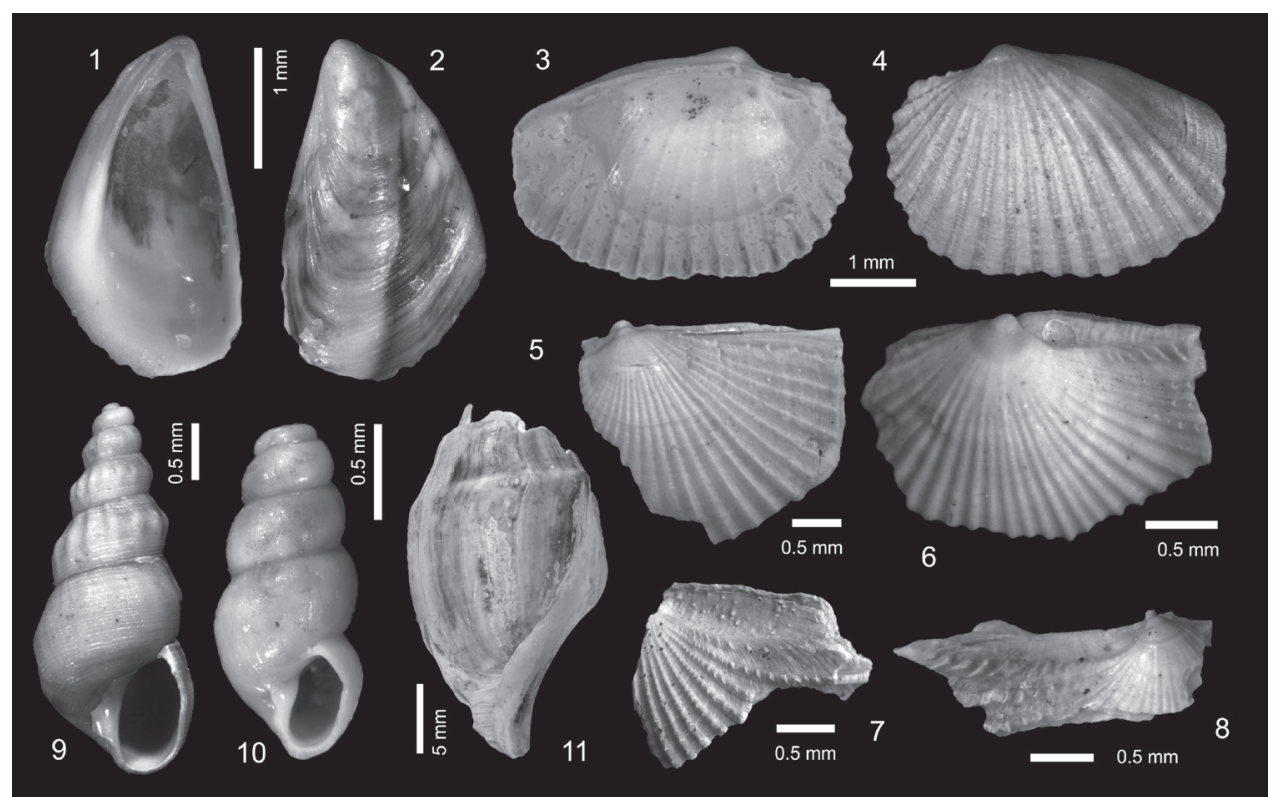

Figure 4: Pannonian macrofossils; bivalves: 1-2: Mytilopsis moesia (Jekelius, 1944) (RKB 5260-29/28), 3-4: Monodacna viennensis (Papp, 1953) (RKB 5260-29/28), 5, 6: Lymnocardium timisense (Jekelius, 1944) (RKB 526026/25), 7, 8: Lymnocardium pseudoobsoletum (Fuchs, 1873) (RKB 5260-25/24); gastropods: 9: Goniochilus haidingeri (Stoliczka, 1862) (RKB 5260-23/22), 10: Socenia soceni (Jekelius, 1944) (RKB 5260-29/28), 11: Melanopsis pseudonarzolina (Papp, 1953) (RKB 5260-54/53). $\mathrm{m}$. The uppermost $\sim 21 \mathrm{~m}$ of the core drilled Holocene/ anthropocene sand and gravel and is not investigated herein.

RKB 7260: Lithologically, the core is rather uniform, comprising clay and silty clay, with few intercalations of fine-to-coarse sand with gravel at 50.1-48.5 m, fine sand at 31.3-28.1 $\mathrm{m}$ and $19.8-18.9 \mathrm{~m}$ as well as a 5-cm-thick sandstone bed at $12.2 \mathrm{~m}$. Samples RKB 7260-60/59 to 7260-58/57 yield moderately rich cardiid assemblages with Polititapes tricuspis, Acteocina lajonkaireana and rare Ervilia dissita. The following samples (7260-57/56, 7260-56/55) are barren of molluscs but contain numerous iron oxide concretions. Lymnocardiid-dominated assemblages appear at RKB 7270-55/54, 7260-50/49 and 7260-47/46, interrupted by intervals with rare cardiids or barren samples. From RKB 7260-46/45 to 7260$32 / 31$, samples are nearly barren of molluscs. Small pyrite tubes are frequent within this interval (RKB 7260$45 / 44,7260-44 / 43$ and 7260-42/41), grading into more spherical pyrite concretions in RKB 7260-41/40 and RKB 7260-32/31. The fauna of the uppermost samples of RKB 7260 is rather poor; barren intervals are common (RKB 7260-23/22, 17/16 and 16/15). Rich Pannonian faunas appear again in the uppermost part of the core (RKB 7260-13/12 to 10/9), including Lymnocardium timisense, Mytilopsis sp., Socenia soceni and numerous ostracods.

\subsection{Foraminifera}

The Sarmatian samples yielded 5351 foraminiferal specimens representing 51 species-level taxa (Appendix 1). Of these, Porosononion granosum accounts for $68.7 \%$ of the total counts, followed by Elphidium hauerinum (8.6\%), Nonion sp. (5\%), Ammonia beccarii (4.1\%), Cycloforina fluviata (2.7\%), Elphidium aculeatum (1.6\%), Bolivina sarmatica (1.3\%) and Pseudotriloculina consobrina (1.3\%) (Fig. 5). All other species account for $<1 \%$ of the fauna.

The statistical analysis of the foraminiferal faunas, based on their percentages per sample, reveals four distinct groups in the cluster analysis (Ward's method), which are also visible in the principal component analysis (PCA) (Fig. 6). Cluster 1 is distinctly separated from the other three clusters and forms a wide scatter in the PCA; the samples of the other clusters are more similar to each other and form a succession in the PCA. 


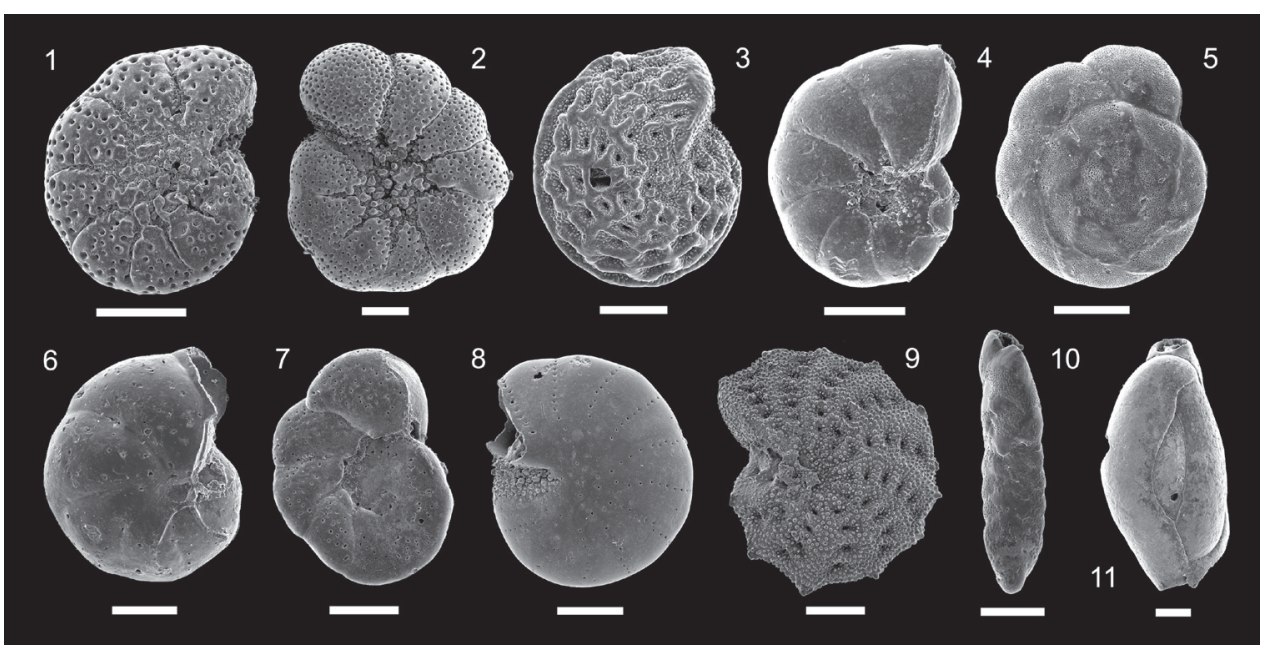

Figure 5: Scanning electron microscopy (SEM) pictures of typical foraminifers from the Sarmatian cores; 1-2: Porosononion granosum (D'Orbigny, 1846) (RKB 5300-36/35); 3: Elphidium hauerinum (D'Orbigny, 1846) (RKB 5300-59/58); 4: Nonion sp. (RKB 5300-34/33); 5: Ammonia beccarii (Linné, 1758) (RKB 5300-33/32); 6-7: Lobatula lobatula (Walker and Jakob, 1798) (RKB 5300-47/46); 8: Elphidiella minuta (Reuss, 1865) (RKB 5300-59/58); 9: Elphidium aculeatum (D’Orbigny, 1846) (RKB 5300-59/58); 10: Bolivina sarmatica (Didkowski, 1959) (RKB 530044/43); 11: Cycloforina fluviata (Venglinski, 1958) (RKB 5300 44/43). Scale bars $=100 \mu \mathrm{m}$.

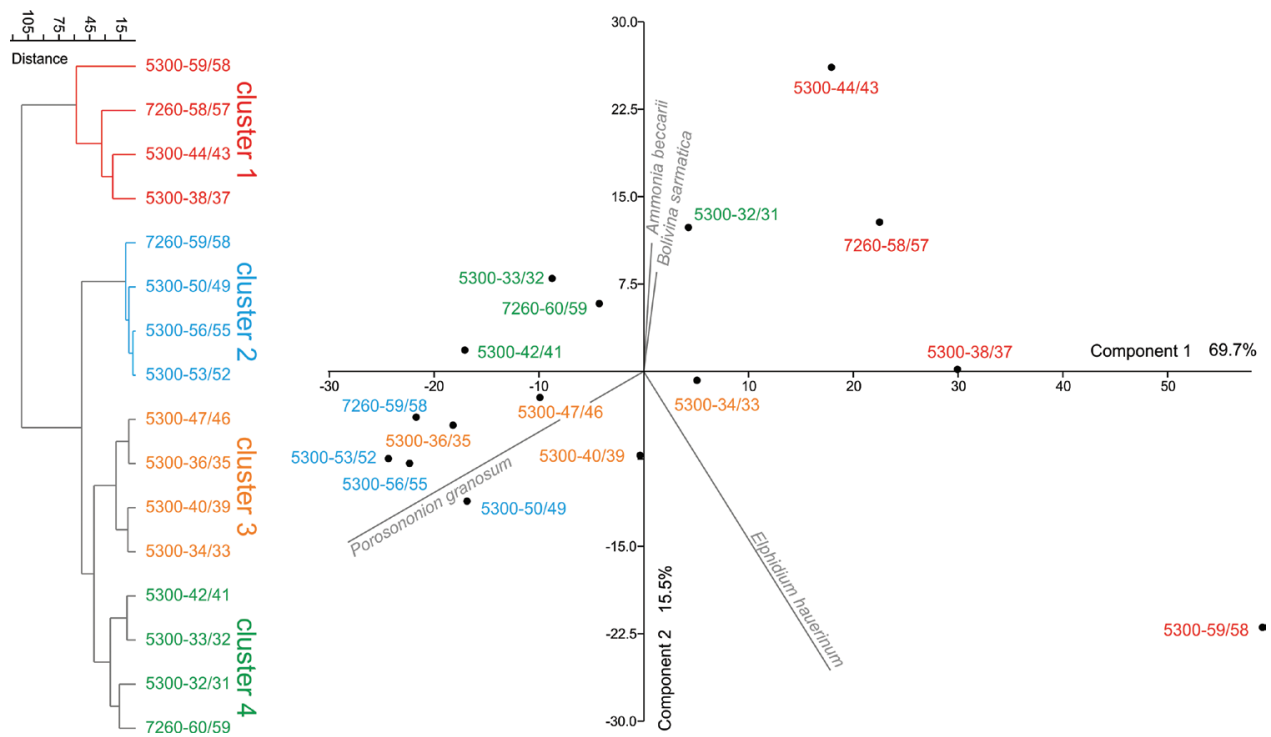

Figure 6: Statistical analyses of the quantitative foraminiferal data (based on percentages per sample). The cluster analysis reveals four distinct groups of samples, which appear also in the principal component analysis. Abundance and presence of Porosononion granosum and/or Elphidium haverinum explain most of the groupings. is characterised by the frequent presence of Porosononion granosum $(64.3 \%-$ $85.7 \%$, mean $=74.7 \%, \sigma=$ 9.0) and moderate contributions by Nonion sp. (11.6\%$18.0 \%$, mean $=14.4 \%, \sigma=2.8$ ) and Elphidium hauerinum (2.3\%-13.7\%, mean $=7.7 \%$, $\sigma=5.3$ ). Cluster 4 (green) is characterised by the occurrence of Porosononion granosum $(60.8 \%-83.4 \%$, mean $=74.4 \%, \sigma=4.8)$, Ammonia beccarii $(0.4 \%-15.8 \%$, mean $=10.5 \%, \sigma=7.2)$ and Cycloforina fluviata (0.4\%-4.8\%, mean $=3.1 \%, \sigma=1.0$ ) and the near absence of Elphidium hauerinum.

Samples of Cluster 1 display low dominance values (0.240.44 , mean $=0.3, \sigma=0.09$ ) and high equitability values (0.50-0.72, mean $=0.64$, $\sigma=0.1$ ). Cluster 2 reveals highest dominance values (0.78-0.86, mean $=0.82, \sigma=$ $0.04)$ and lowest equitability values $(0.19-0.24$, mean $=$ $0.22, \sigma=0.02)$. The other two clusters form a transition between these extremes. Dominance values in Cluster 3 range from 0.46 to 0.75 (mean $=0.59, \sigma=0.12$ ) and from 0.41 to 0.71 (mean = 0.53, $\sigma=0.13$ ) in Cluster 4; their equitability values are also nearly identical: Cluster 3: $0.36-0.61$ (mean $=0.47, \sigma=$ $0.12)$, Cluster 4: $0.31-0.61$ (mean $=0.46, \sigma=0.12$ ).
Aside from Porosononion granosum, ranging from $24.4 \%$ to $44.2 \%$ (mean $=38.6 \%, \sigma=9.5$ ), all samples of cluster 1 (red in Fig. 6) contain Nonion sp. (0.3\%-8.0\%, mean $=3.7 \%, \sigma=3.7)$ and Cycloforina fluviata $(0.3 \%-$ $12.3 \%$, mean $=6.0 \%, \sigma=5.7)$. Considerable heterogeneity in taxonomic composition (e.g. $60.6 \%$ Elphidium haverinum in RKB $5300-59 / 58$ but $0 \%$ in $5300-44 / 43$ ) accounts for the scattering of the samples in the PCA. The main feature separating this cluster from all others is the comparatively low contribution by Porosononion granosum.

All samples of cluster 2 (blue) are characterised by the dominance of Porosononion granosum, ranging from $88.3 \%$ to $92.8 \%$ (mean $=90.3 \%, \sigma=2.3$ ). Cluster 3 (orange)

\subsection{Ostracods}

Nineteen samples from RKB 5300 and 14 from RKB 7260 were investigated for their ostracod content (Fig. 7; Appendix 4). Eight samples were barren of (determinable) ostracods (RKB 5300-32/31, 33/32, 34/33; RKB 7260$26 / 25,32 / 31,55 / 54,56 / 55,59 / 58$ ); shells were frequently fragmented, hampering their identification and detailed quantitative analyses in several samples.

RKB 5300: In the lower part of the core (below the barren samples $5300-32 / 31$ to $34 / 33$ ), only the samples RKB 5300-59/58 and 42/41 yielded noteworthy fauna, which were dominated either by Hemicytheria omphalodes (RKB 5300-59/58) or Cyamocytheridea leptostigma leptostigma (RKB 5300-42/41). Scattered valves of Amnicythere tenuis, 


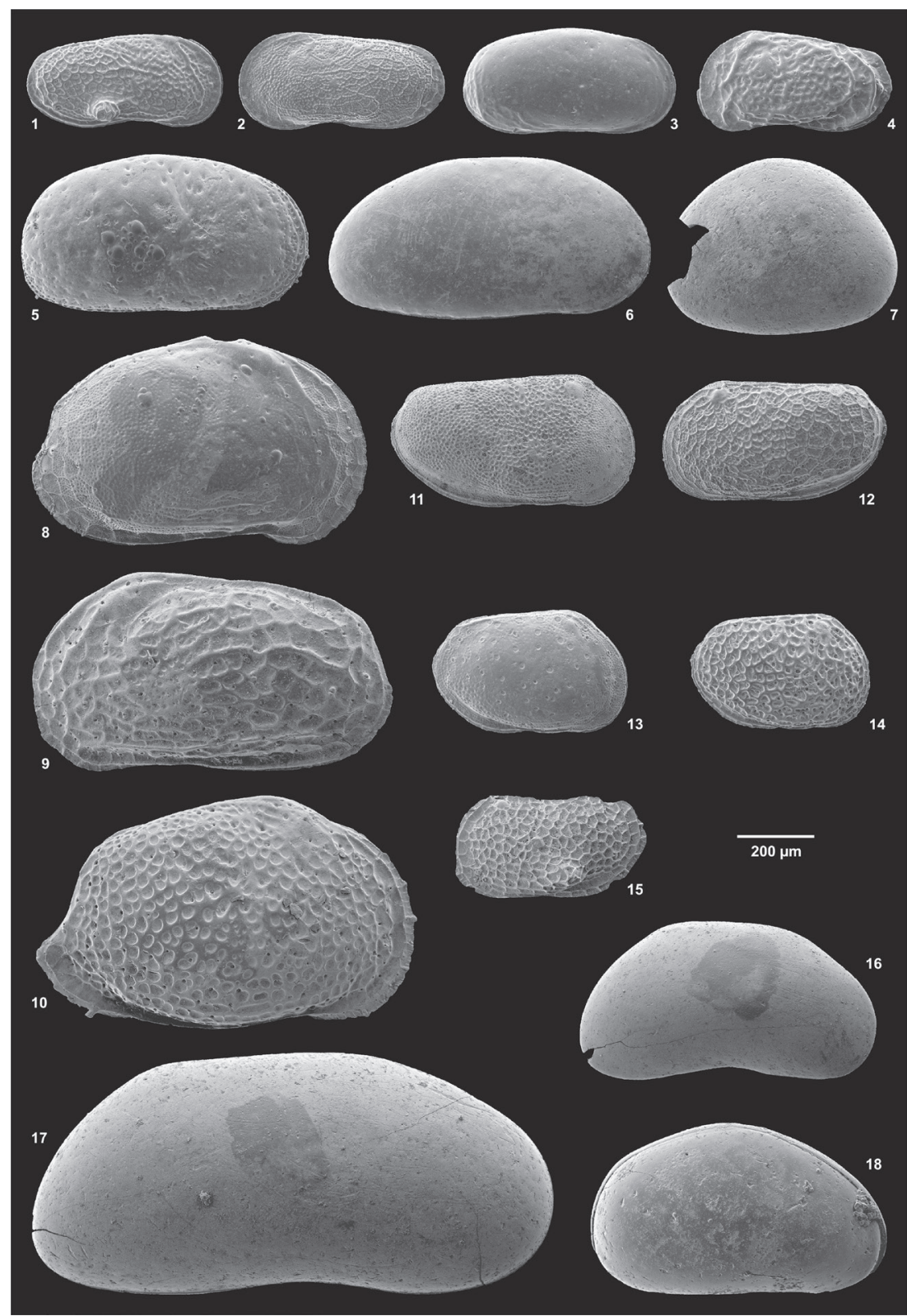

Figure 7: Scanning electron microscopy (SEM) pictures of Sarmatian and Pannonian ostracods 1: Amnicythere cf. monotuberculata (Sokač, 1972) (RKB 5300-28/27); 2: Amnicythere cf. polymorpha (Olteanu, 1989) (RKB 5300-30/29); 3: Amnicythere tenuis (Reuss, 1850) (RKB 5300-53/52); 4 Callistocythere egregia (Méhes, 1908) (RKB 5300-50/49); 5: Cyprideis tuberculata (Méhes, 1908) (RKB 7260-25/24); 6: Cyamocytheridea leptostigma leptostigma (Reuss, 1850) (RKB 5300-42/41); 7: Cypria reniformis (Héjjas, 1892) (RKB 7260-23/22); 8: Hemicytheria hungarica (Méhes, 1908) (RKB 7260-50/49); 9: Hemicytheria omphalodes (Reuss, 1850) (RKB 7260-23/22); 10: Aurila notata (Reuss, 1850) (RKB 7260-58/57); 11: Loxoconcha cf. irregularis (Olteanu, 1986) (RKB 7260-23/22); 12: Loxoconcha kochi (Méhes, 1908) (RKB 7260-23/22); 13: Loxoconcha muelleri (Méhes, 1908) (RKB 5300-28/27); 14: Loxoconcha sp. (RKB 7260-23/22); 15: Loxocorniculina hodonica (Pokorný, 1952) (RKB 5300-30/29); 16: Candona sp. (RKB 7260-23/22); 17: Amplocypris sincera (Zalányi, 1944) (RKB 7260-23/22); 18: Xestoleberis cf. fuscata (Schneider, 1953) (RKB 7260-60/59). Scale bar $=0.200 \mathrm{~mm}$.

Aurila notata, Callistocythere egregia, Cnestocythere sp., Hemicyprideis dacica and Xestoleberis cf. fuscata accompanied these. All mentioned species, except for $A$. tenuis and $H$. omphalodes, were restricted to this part of RKB 5300. Ostracod abundance and diversity increase above the barren interval and peak at sample RKB 5300-28/27, followed by a sharp breakdown at sample RKB 5300-25/24. Leptocytherids, candonids, hemicytherids and loxoconchids shape the assemblages of this core portion, supplemented by rare occurrences of Amplocypris sincera, Cyprideis tuberculata and Herpetocyprella auriculata.

RKB 7260: Up to sample RKB 7260$58 / 57$, only $A$. notata and $X$. cf. fuscata were found. Above two barren samples (RKB 7260-56/55, 55/54), small Cyprideis- and/or Hemicytheria-dominated assemblages followed with $A$. sincera, $C$. egregia, Candona sp., $H$. auriculata and Loxoconcha $\mathrm{cf}$. irregularis as rare, additional elements. Sample RKB 7260-23/22 yielded the most abundant and diverse fauna, with Amnicythere cf. monotuberculata, A. sincera, Candona sp., Cypria reniformis, C. tuberculata, Hemicytheria spp. and loxoconchids.

\subsection{Pollen}

RKB 5300: Four samples (RKB 530038/37, RKB 5300-36/35, RKB 5300-34/33 and RKB 5300-29/28) were analysed, of which only RKB 5300-38/37 and RKB $5300-29 / 28$ gave good results in terms of pollen assemblages (Appendix 3). The lowest sample RKB 5300-38/37 showed high abundance of Ulmus, Quercus, Fagus, Carya, Engelhardia and Liquidambar, suggesting a diverse, mainly deciduous forest mixed with evergreen taxa such as Arecaceae and Cupressaceae (Taxodioideae). Herbs and grasses were only represented by Poaceae (11.03\%), while Pinaceae strongly contributed to the assemblage (Cathaya 10.5\%; Abies 4.6\%; Picea 3.4\% and Tsuga 3.4\%), when Pinus was excluded from all calculations. Otherwise, Pinus would dominate all samples, ranging from $57.6 \%$ in RKB 5300-38/37 to $>60 \%$ in the three remaining samples. Considering all Pinaceae, these values increased from $69.4 \%$ to $>90 \%$. The pollen assemblage of RB 5300-29/28 had a similar stronger contribution of Pinaceae, such as Cathaya (23.3\%), Tsuga (10.7\%) and unidentified Pinaceae (31.5\%). The assemblage composition was similar to that in the samples RKM 5300-38/37 as Quercus, Carya, Ulmus and Fagus were most abundant. Other elements, such as Engelhardia, Sapotaceae, Arecaceae, Liquidambar and Podocarpium podocarpum (= Fupingopollenites wackersdorfensis) were rare in RKB 5300-29/28, while others disappeared from the assemblage in comparison to RKB 530-38/37 (Myrtaceae, Oleaceae, Hamamelidaceae and Rhus). Although not determined further, dinoflatellate cysts were also most abundant in sample RKB 5300-38/37. 
RKB 5300-31/30 yielded almost no organic remains, and in RKB 5300-21/20, all pollen grains were strongly corroded (surface damaged).

RKB 7260: Three samples were analysed (RKB 726054/53, RKB 7260-51/50 and RKB 7260-41/40). Pinaceae strongly dominated all samples, ranging from $79.7 \%$ (RKB $7260-51 / 50$ ) and $83.6 \%$ (RKB 7260-54/53) to $94.0 \%$ (RKB 7260-41/40). Although Pinus was decreasing towards the top of the core, from $62.0 \%$ (RKB $7260-54 / 53$ ) to $36.0 \%$ and $38.0 \%$, the amount of Pinaceae content was increasing (from $6.3 \%$ up to $28.9 \%$ and $33.1 \%$ ), which was mainly a taphonomic signal (poor preservation and fragmentation of other pollen grains).

Similarly, the identification of pollen grains even at the genus level was difficult. Sample RKB 7260-54/53 represented the best pollen assemblage, with a large number of Fagus, Carya, Quercus, Ulmus, Juglans and Tilia. Poaceae $(6.22 \%)$ and Cupressaceae (Taxodioideae; $4.9 \%)$ also significantly contributed to the pollen assemblage, along with the Pinaceae genera Cathaya (20.1\%), Tsuga (9.1\%), Abies (5.3\%) and Picea (5.5\%). Despite the decreasing percentages in RKB 7260-51/50 and RKB $7260-41 / 40$ resulting from the increase in Pinaceae, the angiosperm assemblage was highly similar to that of RKB7260-54/53. RBK 7260-49/48 contained many broken pollen grains, corroded surfaces as well as pyrite inside the pollen grains.

\subsection{Tubular pyrite aggregates}

All cores revealed an interval $~ 3-4 \mathrm{~m}$ thick, with large numbers of black iron sulphide tubes (RKB 530025 to 22 m, RKB 526046 to 43 m, RKB 726045 to $41 \mathrm{~m}$ ). The tubes were slender, elongated, rarely bifurcating and attained length of $\sim 1-2 \mathrm{~mm}$ (in the washing residue) and diameter of $0.2-0.5 \mathrm{~mm}$ (Fig. 8). Smaller specimens were irregular or sub-spherical, but might simply represent fragmented tubes. The walls of the tubes were composed of aggregates of densely spaced pyrite framboids, which displayed a wide range of diameters $(-30-70 \mu \mathrm{m})$ but were rather uniform within an individual aggregate. Based on X-ray diffraction analysis, the tubes consisted of pyrite, without marcasite component. This phenomenon has not been described for Pannonian deposits of the Vienna Basin so far.

\section{Discussion}

\subsection{Biostratigraphy}

High endemism and rapid radiations characterise the middle Miocene Sarmatian and the late Miocene Pannonian aquatic mollusc fauna (Papp, 1953, 1954; Papp et al., 1974; Magyar et al., 1999; Harzhauser and Piller, 2007; Neubauer et al., 2013a, b) and ostracod fauna (Kollmann, 1960; Cernajsek, 1974; Jiř́ček, 1974, 1985; Krstić, 1985; Olteanu, 1989; Zelenka, 1990, 1992; Jiříček and Riha, 1991; Gross, 2004, 2006; Tóth, 2008.). Similarly, the foraminiferal assemblages display rapid shifts in composition throughout the Sarmatian (Cicha et al., 1998). These faunistic successions provide a basis for a biostratigraphic and ecostratigraphic zonation for both stages. Therefore, autochthonous assemblages from the cores can be reliably correlated with these biozones.

Sarmatian: The foraminiferal assemblages of RKB 5300$59 / 58$ to $5300-32 / 31$ and RKB $7260-60 / 59$ to $7260-58 / 57$ are strongly predominated by Porosononion granosum (d'Orbigny, 1846), accounting for $24.4 \%-92.8 \%$ of the total assemblages, partly accompanied by large numbers of Elphidium hauerinum (d'Orbigny, 1846). This faunal type is indicative for the late Sarmatian Porosononion granosum Zone (Papp et al., 1974; Cicha et al., 1998). Cnestocythere, Hemicyprideis dacica and Xestoleberis have their last occurrence in the Central Paratethys during the upper Sarmatian (for ranges of species and references, see Appendix 4). Aurila notata and Cyamocytheridea leptostigma leptostigma are index fossils for the Porosononion granosum Zone. Hence, according to the ostracod record, samples RKB 5300-59/58 to 36/35 and RKB 7260$60 / 59$ to $58 / 57$ are assigned to this zone. The molluscs from RKB 5300-60/59 to 5300-32/31, RKB 5260-60/50 to $5260-57 / 56$ and RKB $7260-60 / 59$ to $58 / 57$ represent typical assemblages of the upper Ervilia Zone of the Sarmatian Stage (Papp, 1956; Harzhauser and Piller, 2004). Characteristic species are Ervilia dissita (Eichwald, 1830), Polititapes tricuspis S.S. (Eichwald, 1829) and Sarmatimactra eichwaldi (Laskarev,
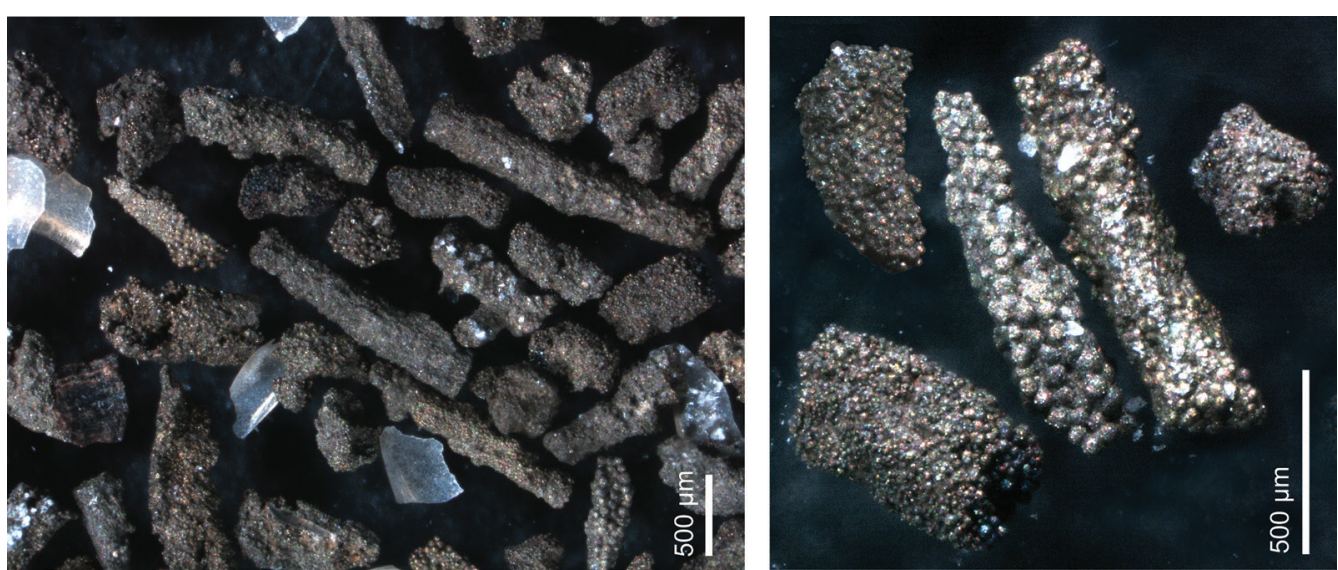
1914). These species differ clearly from their larger and thick-shelled descendants from the younger Sarmatimactra Zone, such as Ervilia dissita podolica (Eichwald, 1830), Polititapes tricuspis ponderosa (d'Orbigny, 1844) and Sarmatimactra vitaliana (d'Orbigny, 1840) (Neubauer et al., 2013a). Therefore, the presence of the Sarmatimactra 
Zone - corresponding to the upper part of the Porosononion granosum Zone - is excluded, and the cores are correlated with the upper Ervilia Zone.

Pannonian: Samples RKB 5300-31/32 to $21 / 22$ yield typical Pannonian ostracod faunas (for ranges of species and references, see Appendix 4). Amnicythere tenuis, Callistocythere egregia, Hemicytheria hungarica and Hemicytheria omphalodes appear also in upper Sarmatian deposits but are restricted to the lower part of the Pannonian (Zones A-C of Papp, 1951; A. tenuis is recorded up to Zone E). Amplocypris sincera spans the Pannonian Zones A-D, Herpetocyprella auriculata from A to E and Cyprideis tuberculata from Zones A to C. However, C. tuberculata, $H$. hungarica and $\mathrm{H}$. auriculata occur characteristically in Zone B of Papp (1951), with which we correlate the sampled interval. The productive samples RKB 7260-54/53 to $23 / 22$ contain taxa known only from Pannonian sediments (except for C. egregia, H. hungarica and H. omphalodes). The found species indicate an early Pannonian age (Zones A-C). The occurrence of C. tuberculata, H. hungarica, $H$. omphalodes and $H$. auriculata argue for an attribution to Zone B of Papp (1951). Melanopsis pseudonarzolina, occurring in RKB 5300-33/32 and RKB 5260-54/53, is characteristic for the lower Pannonian Zone B of Papp (1951), corresponding to the upper part of the Mytilopsis ornithopsis Zone of Harzhauser et al. (2004). Samples RKB 5300-29/28 to 5300-24/23, RKB 5260-51/50 to 5260$38 / 37$ and RKB $7260-55 / 54$ to $7260-10 / 9$ are clearly of Pannonian age, as indicated by the species of lymnocardiids and dreissenids. Lymnocardium pseudoobsoletum is restricted to the early and early middle Pannonian (Zones B-D of Papp, 1951), L. timisense is documented from the early Pannonian (Zones B-C of Papp, 1951), and Mytilopsis moesia is an early Pannonian species (Zones A-C of Papp, 1951) (see Schultz, 2003, for biostratigraphic data for the species). Considering these ranges, we infer an early Pannonian age for the core interval, correlated with the Pannonian Zone B of Papp (1951) and the M. ornithopsis Zone of Harzhauser et al. (2004).

In RKB 5260, samples 5260-29/28 and 5260-23/22 yield Goniochilus haidingeri, which is unknown from the $M$. ornithopsis Zone. It appears in the Mytilopsis hoernesi Zone (Pannonian Zone C of Papp, 1951) (Harzhauser et al., 2002). Similarly, the Melanopsis fossilis flock experiences its first radiation during the $M$. hoernesi Zone (Neubauer et al., 2013b). Therefore, the upper part of RKB 5260 is correlated with this zone. The occurrence of freshwater species and lignitic detritus at RKB 5260-38/37 indicates a possible sequence boundary between the underlying and overlying lacustrine units. Therefore, we tentatively place the boundary between the $M$. ornithopsis and the $M$. hoernesi zones at $\sim 38-37 \mathrm{~m}$. The sample interval RKB $7260-30 / 29$ to $10 / 9$ yields few samples with rich mollusc assemblages; the occurrence of Lymnocardium timisense suggests that this part of the core is still part of the M. hoernesi Zone.

Based on these results, we place the Sarmatian/Pannonian boundary at $31.3 \mathrm{~m}$ in RKB 5300, at $55.5 \mathrm{~m}$ in RKB
5260 and at $57.0 \mathrm{~m}$ in RKB 7260. All these boundaries are distinctly lower than the ones previously proposed by Maslo (2015), who placed the boundary at $30.8 \mathrm{~m}$ in RKB 5300, at $52.5 \mathrm{~m}$ in RKB 5260 and at $50.2 \mathrm{~m}$ in RKB 7260 . The biostratigraphic misinterpretation of the reworked Sarmatian shells, which may be much more abundant than the rare Pannonian elements, explains this discrepancy. For example, sample RKB 5300-31/30 contains a Sarmatian foraminiferal assemblage, mainly comprising Porosononion granosum. In addition, fragmented and abraded shells of Polititapes tricuspis and Obsoletiforma vindobonensis appear in this sample. Although this fauna would thus suggest a Sarmatian age at first sight, the occurrence of Melanopsis pseudonarzolina allows a correlation with the early Pannonian. Moreover, the low diversity and low specimen numbers of the foraminiferal assemblage differ clearly from the same for the Sarmatian samples, supporting our interpretation (Appendix 1).

\subsection{Palaeo-ecology, depositional environment and sea/lake level}

The rich fossil content, coinciding patterns in the MS and occurrence of pyrite tubes allow a reliable crosscorrelation of the cores. The palaeoenvironmental interpretation of these data reveals the presence of two Sarmatian and three Pannonian transgressive-regressive sequences (T-R sequences sensu Catuneanu et al., 2011). These are termed herein SA1, SA2, PA1, PA2 and PA3. An additional Sarmatian sequence is documented from RKB 5320 (Fig. 9), but this interval was not studied by us and it remains open if it represents a T-R sequence.

Sequence SA1 ranges from 60 to $46.6 \mathrm{~m}$ in RKB 5300; it is generally characterised by Ervilia-ChartocardiumInaequicostata-dominated assemblages among the molluscs. Modern Ervilia species are deposit feeders, burrowing in sand and muddy sand. Ervilia prefers intertidal and shallow sublittoral environments at a water depth of $\sim 10-30 \mathrm{~m}$ but ranges down to the continental shelf (Zuschin and Oliver, 2003; Gofas et al., 2011). The mass occurrences of Ervilia dissita in the cores is reminiscent of modern examples, where Ervilia forms boom-and-bust populations dominating benthic ecosystems (Albano et al., 2016). The serpulids in the lower part of SA1 reflect the presence of sea grass or macroalgae to which their tubes are attached. Their subsequent absence correlates with a deepening of the environment. Similarly, the occurrence of Elphidium haverinum, E. aculeatum and Elphidiella minuta and the rare ostracod fauna at the base of core RKB 5300-59/58 indicates a shallow, marine environment. Modern E. aculeatum and E. minuta are typically found in seagrass-dominated environments at 20-30 m depth (Langer, 1993).

Otoliths are also only found in the lower part of SA1. The gadid Paratrisopterus caspius and the sand goby Hesperichthys reductus were common species during the Sarmatian of the Central and Eastern Paratethys (Schwarzhans et al., 2017a, 2017b). Paratrisopterus caspius likely was a euryecious cod, occurring typically in schools 


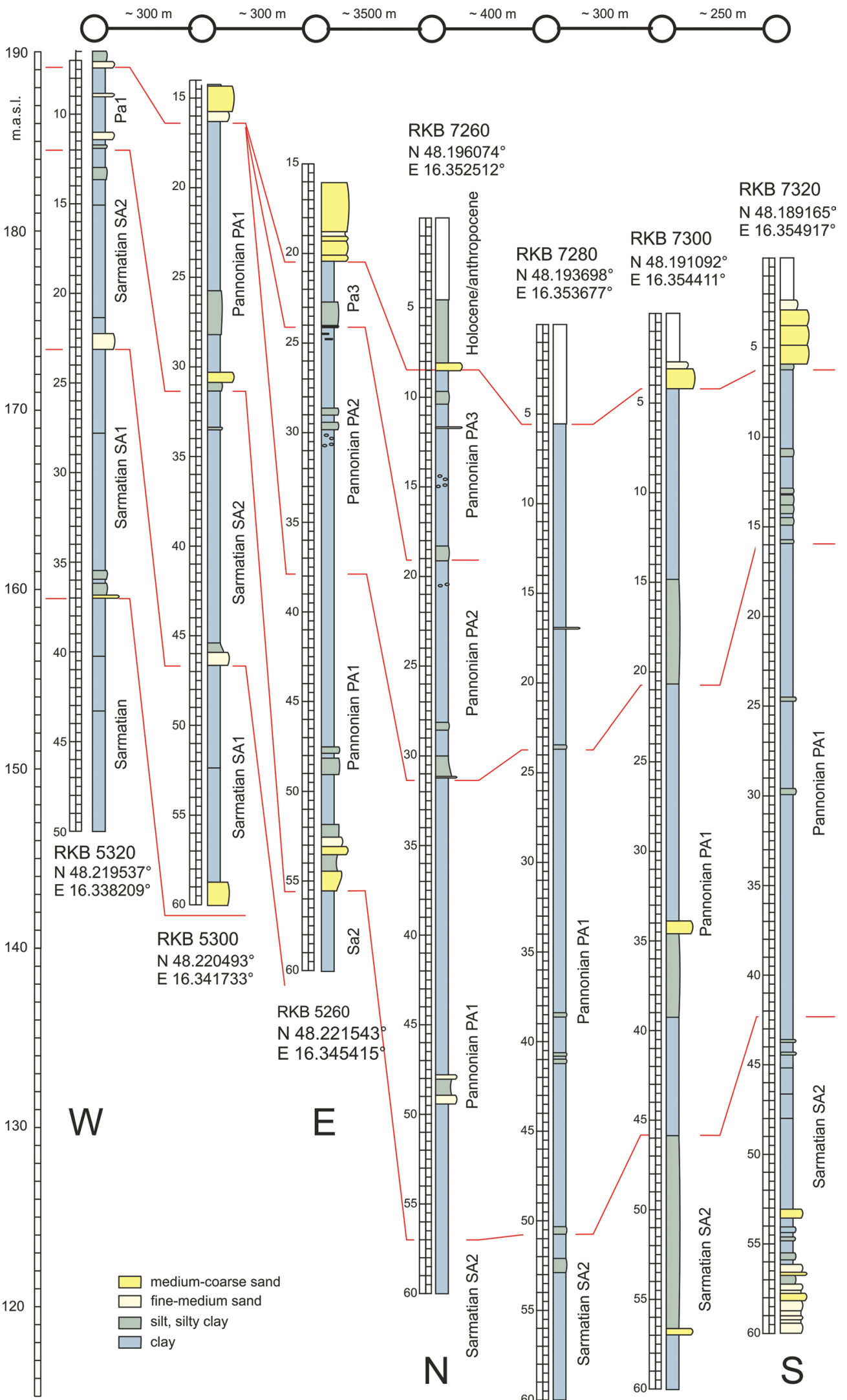

Figure 9: Correlation of boreholes from the basin margin (RKB 5320-5260) and the Vösendorf Basin (RKB 7260-7320).

probably in the epipelagic zone and perhaps also in the uppermost mesopelagic zone above muddy bottoms (Schwarzhans et al., 2017a). Similarly, the epibenthic gobiid Hesperichthys reductus likely inhabited the whole shelf, possibly down to depths of $\sim 200 \mathrm{~m}$ or more, based on the ecological requirements of the closely related extant sand gobies (Schwarzhans et al., 2017b). The thin-shelled Sarmatian cardiid genera are extinct. Similar to modern cardiids, they might have been shallow burrowers in soft sub-strata (Wilson, 1998); although most cardiids inhabit coastal habitats, several genera are adapted to offshore environments (Bosch et al., 1995). The thin-shelled Sarmatian species are generally found in basinal clays, suggesting that they inhabited offshore mud bottom environments (Jekelius, 1944; Papp, 1954).

Modern populations of Porosononion granosum prefer inner neritic environments at a water depth of 80-100 m (AvnaimKatav et al., 2013). Therefore, the strong dominance of Porosononion granosum $(>88 \%)$ and the absence of shallow water taxa in samples RKB-5300-56/55 RKB 5300-53/52 and RKB5300-50/49 suggests a rapid transgression, which peaked around $55 \mathrm{~m}$ in the core. The maximum flooding of SA 1 around 55 to $54 \mathrm{~m}$ also coincides with a peak in MS values.

This interpretation fits well with the assumed Sarmatian palaeogeography, with the coast formed by Alpine rock units situated about $4 \mathrm{~km}$ west of the borehole RKB 5300. Thus, the depositional environment of sequence SA 1 was the shallow- to medium-deep sublittoral type at water depth of several tens of metres at distance of several kilometres from the coast, correlating with the highest 
dominance values in the foraminiferal assemblages. The frequent occurrence of Hesperichthys reductus in this interval might set a limit of several tens of metres for the maximum water depth.

Sequence SA2 starts with a sandy intercalation at $46.6 \mathrm{~m}$ and lignitic clay around 45 to $44 \mathrm{~m}$. Littoral environments became established during this sea level low, as indicated by the frequent occurrence of the batillariid Granulolabium bicinctum, which was restricted to intertidal mudflats and the shoreline (Lozouet et al., 2001; Latal et al., 2006; Lukeneder et al., 2011). Similarly, the epifaunal Lobatula lobatula in RKB 5300-47/46 dwells in high-energy littoral environments (Murray, 2006).

The area was rapidly flooded again and offshore cardiid assemblages took over. Ervilia is subordinate in most parts of the upper part of RKB 5300 from 44 to $31 \mathrm{~m}$. The abundance of Bolivina sarmatica suggests dysoxic conditions, coinciding with an increase in salinity, indicated by the occurrence of Cycloforina. Additionally, the opportunistic Ammonia beccarii and Nonion sp. indicate a shallow water depth and a high nutrient level (Murray, 2006). Infralittoral conditions can be assumed for the almost monospecific (Cyamocytheridea) ostracod sample of RKB 5300 41/42. The maximum flooding of this sequence might be placed at RKB 5300-38/37, where the presence of Bulimina elongata along with fish bones and scales suggests partly dysoxic conditions.

Soon, the medium-deep sublittoral cardiid assemblages were replaced by Polititapes-dominated assemblages. This venerid is usually found in shallow marine coastal palaeo-environments, such as intertidal flats and marine coastal dunes, where it may be a rock-forming element (Neubauer et al., 2013a; Harzhauser and Piller, 2010; Lukeneder et al., 2011). Modern relatives, such as Polititapes aureus (Gmelin, 1791), are shallow burrowers in lower intertidal and subtidal zones, found rarely at higher depths (Bruyne et al., 2013; Oliver et al., 2016). Similarly, the foraminiferal assemblages with high amounts of Ammonia beccarii and miliolids, as well as rare Bolivina and Bulimina, indicate a shallowing as well as the establishment of nutrient-rich coastal environments and tidal flats (Walton and Sloan, 1990). This shallowing is also reflected by the occurrence of the gastropod Melanopsis impressa in RKB 5300-33/32. Extant representatives of Melanopsis live in freshwater streams, rivers, lakes and oases (Bilgin, 1973; Bandel et al., 2007). Thus, although SA2 represents another T-R cycle as SA1, it did not reach the water depth of SA1, and coastal environments were already prograding towards the investigation area during its deposition.

The Sarmatian samples in RKB 5260 are nearly identical with the Polititapes assemblages from RKB 5300. In the context of the geographic closeness of the two boreholes, we consider the $60-55.5 \mathrm{~m}$ core in RKB 5260 to be coeval with the 31.3-36.0 m core of RKB 5300. Similarly, the Sarmatian of RKB 7260 (60-57 m) might be roughly coeval, but due to the much larger distance between the boreholes, a direct correlation is impossible.
This trend in SA1 is also seen in the results of the cluster analysis and the distribution of foram samples within the four clusters. Cluster 1 is characterised by a low occurrence of Porosononion granosum, but the samples show no further similarity to each other and unites samples indicating slightly dysoxic conditions (RKB 5300-44/43, $38 / 37$ ) with samples from seagrass-dominated environments (RKB 5300-59/58). Cluster 2 shows a significant dominance of Porosononion granosum. The low percentage of other taxa suggests a relatively deep inner neritic environment of $\sim 80-100$ m (Langer, 1993), corresponding to the transgression and maximum flooding of SA1. Cluster 3 is defined by a high dominance of Porosononion (although not as high as in Cluster 2), and these samples indicate shallower environments than Cluster 2. This is based on the abundance of Nonion sp. and Elphidium haverinum. The occurrence of Lobatula lobatula in sample RKB 5300-47/46 indicates high water energy (Murray, 2006), which correlates with the sandy sediment in the base of SA2. Cluster 3 combines samples from regressive phases. The samples of Cluster 4 indicate increased salinity based on the abundance of Cycloforina fluviata, miliolids and Ammonia beccarii (Rögl, 1998; Filipescu and Popa, 2001; Murray, 2006).

Sequence PA1 ranges from $31.3 \mathrm{~m}$ to $16.6 \mathrm{~m}$ in RKB 5300 (top truncated by Holocene/anthropocene units), from 55.5 to $38.0 \mathrm{~m}$ in RKB 5250 and from 57.0 to 31.3 $m$ in RKB 7260. The sandy-gravelly basal units of this sequence are only recorded in RKB 5300 and 5260, which are distinctly closer to the palaeo-coast than RKB 7260 . Although palaeontologically identical, the wire-log patterns of these basal units do not allow a direct correlation of the two cores.

Upsection, all three cores reveal a near-identical development, starting with strongly lymnocardiid-dominated fauna. Lymnocardiids settled in littoral to sublittoral offshore environments in Lake Pannon (Geary et al., 2010; Magyar et al., 2016). The delicate, thin-shelled species seem to have been adapted exclusively to muddy offshore bottoms below the wave base (Papp, 1951; cf. Cziczer et al., 2009). Ostracod assemblages from RKB 5300-31/30 to $28 / 27$ and from RKB 7260-54/53 and 50/49 are largely formed by Amnicythere, candonids, Hemicytheria and loxoconchids, which indicate littoral to sublittoral, brackish water environments (Appendix 4). The rare occurrence of the littoral genera Cyprideis and Amplocypris may hint to medium-deep sublittoral water depth. Thus, this unit suggests a rapid transgression of Lake Pannon, covering exposed Sarmatian strata. The absence of typical Pannonian near-shore elements, such as thick-shelled dreissenids (e.g. Congeria, Mytilopsis), supports this interpretation. This lymnocardiid-dominated interval displays a 'bulge' of high MS values in all cores (Fig. 10), ranging from 27.5 to $30.0 \mathrm{~m}$ in RKB 5300, from 48.5 to $51.5 \mathrm{~m}$ in RKB 5260 and from 48.5 to $51.0 \mathrm{~m}$ in RKB 7260. In all cores, this interval is followed by a prominent negative peak in MS values from 26.5 to $27.5 \mathrm{~m}$ in RKB 5300, 47.5 to $48.5 \mathrm{~m}$ in RKN 5260 and from 46.5 to $47.0 \mathrm{~m}$ in RKB 7260. In all 

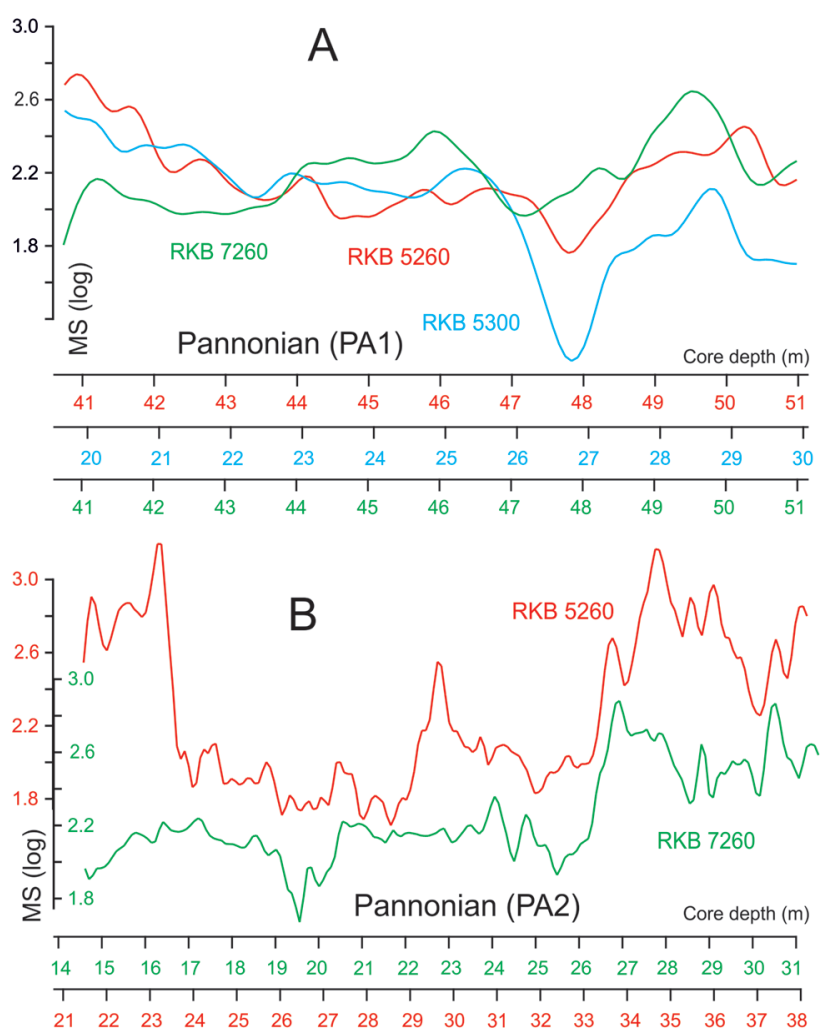

Figure 10: Comparison of patterns in magnetic susceptibility (log-transformed, 21-point Gaussian filter). Largely coinciding patterns from the two Pannonian sequences PA1 (A) and PA2 (B) suggest synchronous deposition of the respective intervals and provide potential tie points for cross-correlation. Strongly dissimilar intervals (upper $4 \mathrm{~m}$ in B) reflect different depositional histories.

cores, an interval of $\sim 3-4 \mathrm{~m}$ thickness with pyrite tubes sets in $2 \mathrm{~m}$ above the negative MS peak. Consequently, we propose that these units are strictly coeval in all cores, allowing a precise correlation. Dysoxic lake bottom conditions are indicated by the near absence of molluscs and ostracods in the upper part of PA1. A slight shallowing is only indicated in the uppermost part of the sequence by occasional occurrences of reworked Sarmatian shells. Moreover, the presence of iron oxide concretions might indicate better oxygenation.

Sequence PA2 ranges from 38.0 to $24.4 \mathrm{~m}$ in RKB 5260 and from 31.3 to probably $12.1 \mathrm{~m}$ in RKB 7260 . The base of this sequence is documented in RKB 5260-38/37 by lignitic clay with Theodoxus sp., which is an obligate freshwater genus (Welter-Schultes, 2012). Its occurrence is related to riverine influx or the establishment of a freshwater lake, fringing Lake Pannon. Littoral, brackish water conditions are also indicated by the Cyprideis-dominated ostracod fauna of RKB 7260-30/29. In RKB 7260, this phase of lowered lake level corresponds to the occurrence of poorly sorted fine-to-medium sand from 31.3 to $30.0 \mathrm{~m}$, followed by a rapid lake-level rise leading to dysoxic conditions in the lower part of the sequence (up to $30 \mathrm{~m}$ in RKB 5260). Irregular-to-spherical pyrite concretions are frequent, pointing to anaerobic conditions in the sediment; dysoxic bottom conditions resulted in impoverished mollusc faunas.
Conditions became more favourable for settlement by lymnocardiids again in the upper part of the sequence. An increase in sand and fine gravel content and lignitic layers suggests a general shallowing trend from 30 to $23 \mathrm{~m}$ in RKB 5260. Consequently, the mollusc fauna becomes more diverse, and species of shallow sublittoral and coastal deltaic lake environments appear (e.g. Socenia soceni, Goniochilus haidingeri and Melanopsis sp.). Similar assemblages have been also described from the near-shore settings of Lake Pannon in the Vienna Basin (Papp, 1953) and the Eisenstadt-Sopron Basin (Harzhauser et al., 2002).

The similarity in the MS patterns in Sequence 2 allows a direct correlation of the core intervals at 38-24 $\mathrm{m}$ in RKB 5260 and 32-17 m in RKB 7260 (Fig. 10). The lower part with pyrite concretions is characterised by high values in both cores, followed by a rapid shift towards lower values at $27 \mathrm{~m}$ in RKB 7260 and at $33 \mathrm{~m}$ in RKB 5260. At $24.3 \mathrm{~m}$ in RKB 5260 and $17 \mathrm{~m}$ in RKB 7260, the MS patterns become very dissimilar and a correlation becomes impossible. No sedimentological and palaeontological change is seen in RKB 7260 above this point up to the sandstone layer at $12.1 \mathrm{~m}$. The interval above is characterised by increasing amounts of sand and thus differs from the underlying clays. Therefore, we tentatively place the boundary between PA2 and PA3 in RKB 7260 at 12.1 $m$. This implies that the more basinal RKB 7260 preserved about $5 \mathrm{~m}$ more sediment of PA2, which is missing in RKB 5260 , where already lignitic sand of PA3 is cored at the same horizon.

Sequence PA3 starts with lignitic sand and lignite layers at $24.3 \mathrm{~m}$ in RKB 5260. In terms of MS values, the base of PA3 coincides with an abrupt shift towards higher values. As discussed earlier, the onset of sandstone intercalations at $12.1 \mathrm{~m}$ might form the base of PA3 in RKB 7260 . The barren intervals and the presence of rare lymnocardiids point to an unfavourable environment, probably with dysoxic conditions in the medium-deep sublittoral zone for the upper part of PA2 in RKB 7260, whereas the rich mollusc fauna in the base of PA3 in RKB 7260, with numerous lymocardiids, dreissenids and Socenia socenia, indicates an oxic near-shore environment.

\subsection{Hinterland vegetation}

The vegetation around the Sarmatian Sea and Lake Pannon was mainly characterised by a diverse deciduous forest (Quercus, Fagus, Ulmus, Carya and Juglans), with few evergreen taxa (Arecaceae, Oleaceae, Myrtaceae and Tsuga) (e.g. Wilen and Tiner, 1993; Thompson et al., 1999a, b; Brach and Song, 2006; de Rigo et al., 2016). Pollen grains of riparian vegetation are rare, but the presence of Nyssa as well as certain Taxoidoideae pollen grains indicates at least a small amount of coastal forested wetlands (Thompson et al., 1999a, b; Averyanov et al., 2009; Lodge, 2016), inhabited also by members of the Cyperaceae, Chenopodioideae or Poaceae (Willard et al., 2001; Britton and Crivelli, 1993). Equally rare are representatives of vegetation from inflowing rivers such as Sparganium or 
Salix. Elements of a higher elevation are mainly represented by Abies and Picea (Jimenez-Moreno et al., 2008; de Rigo et al., 2016). As all pollen counts show a minimum of $\sim 69.4 \%$ of saccate Pinaceae, long-distance transport of all pollen grains is likely and indicates a large distance to the shoreline (e.g. Hopkins, 1950; Traverse and Ginsberg, 1966; Smirnov et al., 1996).

The highest abundance of warm temperate-to-tropical elements clearly occurs in the Sarmatian sample RKB 5300-38/37. These are represented by the highest numbers of Arecaceae, Sapotaceae, Liquidamber, Platycarya, Engelhardia, Hamamelidaceae, Myrtaceae as well as the Fabaceae Podocarpium podocarum (= Fupingopollenites wackersdorfensis) (Planderova, 1990; Thompson et al., 1999a, b; Brach and Song, 2006).

Taxa indicating a warm climate, such as Eleagnus, Platycarya, Reevesia, Rhamnaceae, Zanthoxylum and Symplocos, are also present in the Pannonian samples (RKB 5300-28/29, RKB 7260-53/54 and RKB 7260-51/50). Although some of these taxa are known from other Pannonian localities (e.g. Harzhauser et al., 2008; Kern et al., $2012 a, b, 2013)$, the presence of these in an offshore core could also be the result of reworking (e.g. Tricolporopollenites striatoreticulatus and Liliacidites sp. in sample RKB 5300-29/28; see also Planderova, 1990). Generally, lower diversity and poor preservation suggest a more distal position of RKB 7260 compared to RKB 5300, which agrees with its assumed more-basinal palaeogeographic position.

The co-existence approach (CA) was applied for the Sarmatian sample RKB 5300-38/37 and for the Pannonian samples RKB 5300-29/28, RKB 7260-54/53, RKB 7260$51 / 50$ and RKB 7260-41/40.

For the Sarmatian and the Pannonian samples, the CA indicates a mean annual temperature ranging from 13.8 to $21.7^{\circ} \mathrm{C}$ and a seasonal variation of $3.1-15.1^{\circ} \mathrm{C}$ for the coldest month's temperature and $23.6-28.3^{\circ} \mathrm{C}$ for the warmest month. The mean annual precipitation ranges from 740 to $1551 \mathrm{~mm}$ for the Sarmatian assemblage and from 740 to 1724 mm for the Pannonian ones. The Sarmatian dry season ranges from 17 to $64 \mathrm{~mm}$ and from 8 to $93 \mathrm{~mm}$ for the Pannonian assemblages. Similarly, the wettest month is similar for both time slices, ranging from 150 to $241 \mathrm{~mm}$ for the Sarmatian and from 150 to $343 \mathrm{~mm}$ for the Pannonian. Rainfall was more likely during the warmer season as the precipitation of the warmest month ranges from 79 to $189 \mathrm{~mm}$ (Sarmatian) and 79 to $224 \mathrm{~mm}$ (Pannonian).

Since the CA considers only the presence/absence of taxa, long-distance transport of the pollen results in reduced diversity, which negatively affects the accuracy of the CA intervals. Although our data are comparable with those in previous studies (Bruch et al., 2004; 2006; Harzhauser et al., 2008; Jimenez-Moreno et al, 2008), the co-existence intervals for the RKB cores are less precise. Therefore, the CA results in wide and rather similar climate interpretations for the Sarmatian and the early Pannonian. Overall, however, the number of thermophilous taxa is higher during the late Sarmatian.

\subsection{Authigenic tubular pyrite aggregates as indicator for severe sub-surface anoxia}

The interval of about 3-4 m thickness with pyrite tubes is a striking feature appearing more or less in the middle of the PA1 sequence. Such pyrite tubes have been frequently detected close to the surface in near-anaerobic marine shelf sediments (e.g. Sassen et al., 2004; Xie et al., 2013; Zhang et al., 2014; Lin et al., 2014, 2016). Sulphate-driven anaerobic oxidation of methane (AOM) by methanotrophic archaea and sulphate-reducing bacteria is the favoured model to explain the authigenic formation of tubular pyrite aggregates in marine sediments (McGlynn et al., 2015; Wegener et al., 2015; Zhang et al., 2014; Lin et al., 2016). AOM, however, is not restricted to marine environments but is also documented for brackish water and freshwater sediments (Wu et al., 2009; Deutzmann and Schink, 2011; Egger et al., 2015). In lakes, methane is mainly formed biologically by methanogenic archaea in anoxic environments (Bastviken et al., 2004; Deutzmann and Schink, 2011), thus providing the source for AOM.

The initial cause for the tubular morphology of the pyrite aggregates is still under discussion. The tubes were interpreted as pseudomorphoses of large sulphideoxidising bacteria (Sassen et al., 2004) and as microburrows (Rao et al., 2008). Burrows are unlikely explanations for the Pannonian pyrite tubes as the various ichno-fossils described from Lake Pannon deposits are much larger in diameter (Magyar et al., 2006; Hyžný et al., 2015). Similar to the Pannonian pyrite tubes, Lu et al. (2007) and Lin et al. (2016) observed branching in some tubes and therefore interpreted them as micro-channels created by upward-moving fluids in the sediment.

In any case, the pyrite formation occurs within the sediment at some distance from the sediment surface, ranging from few tens of centimetres to several metres (Lin et al., 2014, 2016; Zhang et al., 2014). Therefore, a temporal offset between the time of pyrite formation and the co-occurring sediment and fossil content of the respective sample has to be considered. This temporal offset explains the mass occurrence of ostracods in some of the samples from the pyrite interval. Dysoxic conditions seem to have also persisted during most of the deposition of the upper part of this first Pannonian sequence, as reflected by the near absence of molluscs. At the same time, anoxic conditions developed in the sediment, giving rise to $A O M$.

Interestingly, no such pyrite tubes have been described from other dysoxic or anoxic deposits of Lake Pannon (e.g. Starek and Pipík, 2007; Magyar et al., 2006; Harzhauser et al., 2008; Kern et al., 2012a, b). All these records, however, are younger then the PA1 sequence, ranging roughly from 10 to $8 \mathrm{Ma}$. At that time, the salinity of the initially brackish lake water had already decreased (Geary et al., 1989; Mátyás et al., 1996; Harzhauser et al., 2007), and the climate had shifted towards humid conditions (Harzhauser et al., 2007; Böhme et al., 2008). Maybe changes in water chemistry, such as availability of 
sulphate, played a major role in the formation of tubular pyrite aggregates in Lake Pannon.

\subsection{Gaps, temporal coverage and tectonics}

Based on cross-correlations with cyclo-stratigraphic and/or palaeomagnetic core data from the Vienna Basin, the Sarmatian and Pannonian biozones were tentatively correlated with the international chronostratigraphic chart by Harzhauser and Piller (2004), Harzhauser et al. (2004), Lirer et al. (2009) and Paulissen et al. (2011). Although these proposals may be criticised for some vague and weak points, they provide rough constraints for the time represented by each of the biozones (Fig. 11). Accordingly, the upper Ervilia Zone spans an interval from $\sim 12.1$ to $\sim 11.9 \mathrm{Ma}$ (Harzhauser and Piller, 2004). The upper Sarmatian Sarmatimactra Zone and the lowermost Pannonian Zone (Zone A of Papp, 1951) are missing in the cores. The subsequent Mytilopisis ornithopsis Zone (without Zone A) corresponds to an interval of $\sim 11.5-11.2 \mathrm{Ma}$ (Harzhauser et al., 2004; Neubauer et al., 2013b), indicating a gap of at least 400 ka between the Sarmatian SA2 and Pannonian PA1 sequences in the RKB boreholes. Within the M. ornithopsis Zone, the first major transgression of Lake Pannon occurred between 11.308-11.263 Ma (Gross et al., 2011), which is a likely time frame for the PA1 sequence.

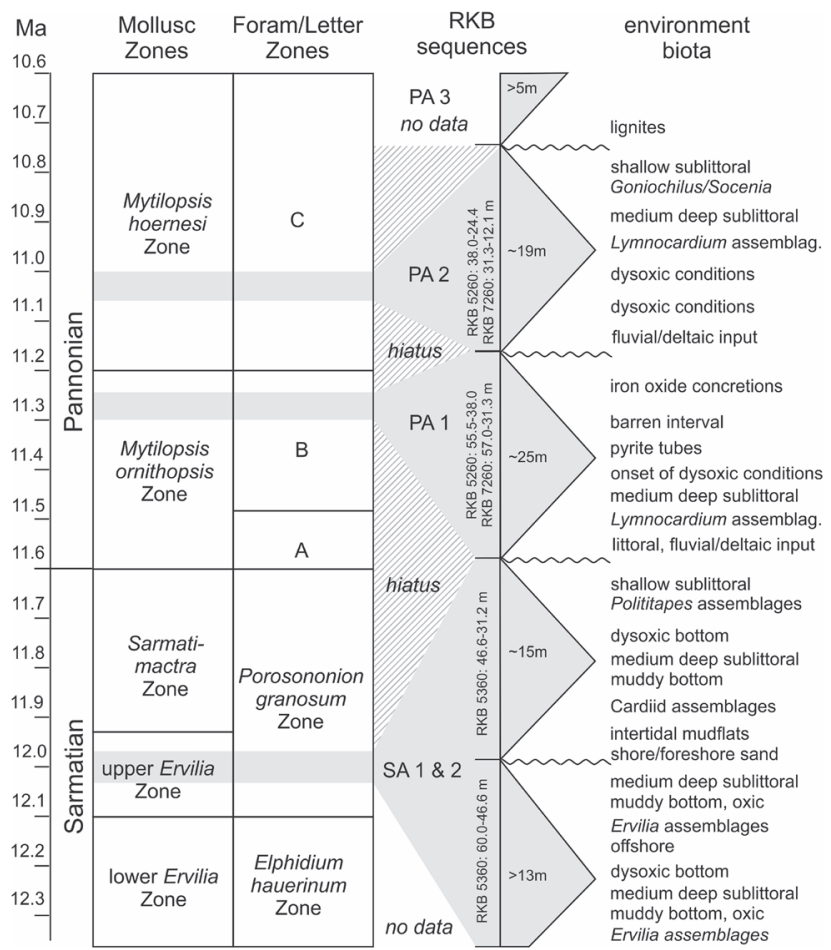

Figure 11: Chronostratigraphic and biostratigraphic correlations of the SA1, SA2, PA1 and PA2 sequences (in grey), indicating maximum thickness in the RKB cores and typical biotic and palaeo-environmental features. Note that the correlation of the sequences within the biozones is somewhat tentative, and they are correlated with transgressive phases of the Paratethys Sea and Lake Pannon. The temporal coverage of each sequence follows sediment accumulation rate estimates with large error bars (see Discussion section).
The next hiatus occurs at the boundary between PA1 and PA2, separating the $M$. ornithopsis Zone from the overlying $M$. hoernesi Zone. The $M$. hoernesi Zone covers roughly an interval from 11.2 to $10.6 \mathrm{Ma}$. The boundary between the two zones is marked by a lake-level fluctuation (Kováč et al., 1998), expressed by the progradation of large fluvial deltas into the Vienna Basin (Harzhauser et al., 2004). The first major flooding of this zone, which also reached higher parts of the basin margin, such as the Mistelbach Block north of Vienna, occurred around 11.111.0 Ma (Harzhauser, 2009). Therefore, we infer a further hiatus spanning 100-200 ka in the RKB cores.

Within these biostratigraphically defined frame, further constraints can be deduced from the thickness of each sequence and assumed sedimentation rates. The Sarmatian sequences $S A 1$ and SA2 reach about 13 and $15 \mathrm{~m}$ in RKB 3000. Both are incomplete, as the base of SA1 was not cored and the top of SA2 is truncated by the overlaying PA1. Similar thicknesses are observed in the neighbouring borehole RKB 5320 (Fig. 9), which also reveals an additional underlying Sarmatian sequence (not studied herein). Considering the first Pannonian sequence to be coeval in all cores, with distinct marker horizons such as the negative MS peak and the zone of pyrite formation, the result shows that sedimentation in RKB 7260 commenced earlier than in RKB 5300/5260. Thus, the lowermost Pannonian deposits in RKB 7260, from 51.0-57.0 $\mathrm{m}$, are missing in the other cores, which fits the assumed more-distal, offshore setting of RKB 7260. In this core, PA1 reaches $\sim 25 \mathrm{~m}$ and PA2 $\sim 19 \mathrm{~m}$ in thickness (Figs 2, 11). A nearly identical thickness of PA1 is documented from the neighbouring boreholes RKB 7280-7320 (Fig. 9). The sedimentation rates for these sequences cannot be reconstructed directly due to the lack of absolute tie points. Nevertheless, several papers dealt with Sarmatian and Pannonian sediment accumulation rates in the Vienna Basin. Based on magnetostratigraphically backboned cyclostratigraphy, Paulissen et al. (2011) reconstructed very high sedimentation rates of $1.2 \mathrm{~m} /$ ka for the late Sarmatian and very low rates of $0.3 \mathrm{~m} / \mathrm{ka}$ for the lacustrine Pannonian. These data were derived from a borehole situated close to a tectonically active zone off the palaeocoast and might not be representative for more coastal settings. Lirer et al. (2009) arrived at an average sedimentation rate of $\sim 0.65 \mathrm{~m} / \mathrm{ka}$ for the Sarmatian and Pannonian for a borehole situated at the junction from coastal shoal to basin. Even higher sedimentation rates of $0.73 \mathrm{~m} / \mathrm{ka}$ were proposed by Kern et al. (2012a) for the middle Pannonian for a setting below wave base. This borehole was situated at a distance of $\sim 5 \mathrm{~km}$ from the shore within the sphere of influence of a delta (Harzhauser et al., 2008). Applying the Lirer/ Kern estimates results in a duration of $\sim 18-20$ kyr for SA1 and $\sim 21-23 \mathrm{kyr}$ for SA2. PA1 represents $\sim 34-38 \mathrm{kyr}$ and PA2 26-29 kyr. Without additional constraints and tie points, this hypothesis cannot be tested. Nevertheless, these calculations illustrate that surprisingly little time is represented by the sediments and that the gaps are 
much larger than would be deduced from biostratigraphy alone (Fig. 11).

Using the coeval peaks in the MS pattern to correlate the cores reveals a tectonic offset of $25 \mathrm{~m}$ between RKB 5300 and RKB 5260. With respect to the short distance between the boreholes of $\sim 300 \mathrm{~m}$, a single - so far undetected fault seems to separate the two blocks. A second fault separates RKB 5300 from RKB 5320 in the west (Fig. 9). Both faults are part of a SSW-NNE-trending fault branching off from the junction between the Bisamberg Fault in the north and the Leopoldsdorf Fault system in the south and east (Fig. 1). This large unnamed fault, which is indicated on the tectonic map by Kröll and Wessely (1993) and Lee and Wagreich (2016), separates the basin margin with RKB 5260 and RKB 5300 from the Vösendorf Basin in which RKB 7260 was drilled. The tectonic offset between RKB 5260 and RKB 7260 ranges $\sim 17 \mathrm{~m}$. For both faults, the tectonic activity must have postdated the Pannonian $M$. hoernesi Zone and is thus younger than 10.6 Ma, corresponding to the middle Pannonian tectonic subsidence phase of Hölzel et al. (2008).

\section{Conclusions}

The investigated boreholes from the City of Vienna allow a detailed reconstruction of the marine and lacustrine depositional environments during the late Sarmatian and early Pannonian periods at the margin of the Vienna Basin. At least three Sarmatian T-R sequences, each reaching $\sim 15 \mathrm{~m}$ thickness, are recorded from the westernmost cores. Of these, the upper two sequences have been studied herein, and these reveal two rapid transgressions peaking in offshore conditions, with medium-deep sublittoral soft bottom environments at water depth of several tens of metres. A large distance from the shore is also indicated by the pollen assemblages, which are strongly dominated by Pinus. Both sequences span a narrow part of the upper Ervilia Zone; no younger Sarmatian deposits are recorded in any of the cores and a hiatus of 600 ka separates the Sarmatian from the subsequent Pannonian deposits. A major transgression during the early Pannonian ( $M$. ornithopsis Zone) flooded the area rapidly again. In more distal settings, sedimentation commenced slightly earlier with clay and silt, whereas coarse sand, gravel and reworked Sarmatian fauna characterised the marginal areas. Soon, sublittoral offshore conditions established in the entire study area, again indicated by low diversity of the pollen assemblages. Hospitable environmental conditions on the muddy lake bottom, which was settled by numerous lymnocardiids, soon deteriorated, leading to a severe decline of benthic molluscs. During the maximum flooding, the lake bottom became hostile. Sulphate-driven anaerobic oxidation of methane by archaea and sulphate-reducing bacteria became widespread within the sediment, resulting in a distinct horizon of tubular pyrite aggregates, which have not been detected in Lake Pannon so far. Another hiatus of at least 200 ka separates these deposits from the second Pannonian sequence, which is correlated with the $M$. hoernesi Zone. The second transgression by Lake Pannon on the basin margin led again to medium-deep sublittoral conditions and dysoxic bottom conditions, but shallow sublittoral conditions with a rich benthic mollusc fauna established soon during subsequent shallowing, which peaked in lignite formation. A third Pannonian sequence, belonging still to the $M$. hoernesi Zone, is only partly recorded by the cores and is not discussed in detail.

Throughout the investigated boreholes, the two Pannonian sequences reach a thickness of $\sim 19-25 \mathrm{~m}$. Sedimentation rates from other Pannonian sections in the Vienna Basin suggest a duration of $<40$ ka for the formation of each of these sequences. Consequently, the seemingly continuous cores captured relatively short glimpses of geological time. Only careful biostratigraphic and palaeo-ecological analyses of the cores are able to detect these hidden gaps, which may turn into pitfalls for palaeomagnetics.

\section{Acknowledgements}

This paper is part of the project "The Sarmatian/Pannonian Extinction Event within the City of Vienna", which was supported by the Cultural Department of the City of Vienna and the Commission for Geosciences of the Austrian Academy of Sciences. We thank Vera Hammer (Natural History Museum, Vienna) for the X-ray diffraction analysis of the pyrite tubes and Jörn Peckmann (University Hamburg) for discussions on the origin of these structures.

We thank Gerhard Hobiger (Department of Geochemistry, Geological Survey Austria) for preparation of palynological samples and Michael Wagreich (University of Vienna) and Imre Magyar (Hungarian Natural History Museum, Budapest) for constructive reviews.

\section{References}

Albano P.G., Filippova N., Steger J., Kaufman D.S., Tomašových A., Stachowitsch $M$. and Zuschin M., 2016. Oil platforms in the Persian (Arabian) Gulf: living and death assemblages reveal no effects. Continental Shelf Research, 121, 21-34. https://doi.org/10.1016/j. csr.2015.12.007

Averyanov, L.V., Phan, E.L., Nguyen, T.H., Nguyen, S.K., Nguyen, T.V. and Pham, T.D., 2009. Preliminary observations of native Glyptostrobus pensilis (Taxodiaceae) stands in Vietnam. Taiwania, 54, 191-212. https://doi. org/10.6165/tai.2009.54(3).191

Avnaim-Katav, S., Almogi-Labin, A., Sandler, A. and Sivan, D., 2013. Benthic foraminifera as palaeoenvironmental indicators during the last million years in the eastern Mediterranean inner shelf. Palaeogeography, Palaeoclimatology, Palaeoecology, 386, 512-530. https://doi. org/10.1016/j.palaeo.2013.06.019

Bandel, K., Sivan, N. and Heller, J., 2007. Melanopsis from Al-Qarn, Jordan Valley (Gastropoda: Cerithioidea). Paläontologische Zeitschrift, 81, 304-315. 
Bastviken D., Cole J., Pace M. and Tranvik L., 2004. Methane emissions from lakes: dependence of lake characteristics, two regional assessments, and a global estimate. Global Biogeochemical Cycles, 18, 1-12.

Bilgin, F. H., 1973. Studies on the functional anatomy of Melanopsis praemorsa (L.) and Zemelanopsis trifasciata (Gray). Proceedings of the Malacological Society of London, 40, 379-393. http://onlinelibrary.wiley.com/ doi/10.1029/2004GB002238/abstract

Böhme, M., Ilg, A. and Winkelhofer, M., 2008. Late Miocene "washhouse" climate in Europe. Earth and Planetary Science Letters, 275, 393-440. https://doi.org/10.1016/j. epsl.2008.09.011

Borgh, M., ter, Vasiliev, I., Stoica, M., Knežević, S., Matenco, L., Krijgsman, W., Rundić, L. and Cloetingh, S., 2013. The isolation of the Pannonian basin (Central Paratethys): New constraints from magnetostratigraphy and biostratigraphy, Global and Planetary Change 103 99-118. https://doi.org/10.1016/j.gloplacha.2012.10.001

Bosch, D.T., Dance, S.P., Moolenbeek, R.G and Oliver, P.G., 1995. Seashells of Eastern Arabia. Motivate Publishing, Dubai, 296 pp.

Brach, A.R. and Song, H., 2006. eFloras: New directions for online floras exemplified by the Flora of China Project. Taxon, 55, 188-192.

Britton, R.H. and Crivelli, A.J., 1993. Wetlands of southern Europe and North Africa: Mediterranean wetlands. In: Whigham, D.F., Dykyjová, D. and Hejný, S. (Eds.): Handbook of Vegetation Science, Wetlands of the World I: Inventory, Ecology and Management. Kluwer Academic Publishers, Dordrecht, pp. 129-194. ISBN 978-94-015-8212-4

Brix, F., 1988. Jungtertiär und Quartär. In: F. Brix and B. Plöchinger (eds.), Erläuterungen zu Blatt 76 Wiener Neustadt. Geologische Karte der Republik Österreich 1:50.000, Geologische Bundesanstalt Wien, pp. 29-85.

Bruch, A.A., Utescher, T., Alcalde Olivares C., Dolakova, N. and Mosbrugger, V., 2004. Middle and Late Miocene spatial temperature patterns and gradients in Central Europe - preliminary results based on palaeobotanical climate reconstructions. Courier Forschungsinstitut Senckenberg, 249, 15-27.

Bruch, A.A., Utescher, T., Mosbrugger, V., Gabrielyan, I. and Ivanov, D.A., 2006. Late Miocene climate in the circum-Alpine realm - a quantitative analysis of terrestrial palaeofloras. Palaeogeography, Palaeoclimatology, Palaeoecology, 238, 270-280. https://doi.org/10.1016/j. palaeo.2006.03.028

Bruyne, R.H. de, van Leeuwen, S.J., Gmelig Meyling, A.W. and Daan, R., 2013. Schelpdieren van het Nederlandse Noordzeegebied. Ecologische atlas van de mariene weekdieren (Mollusca). Tirion Uitgevers, Utrecht en Stichting Anemoon, Lisse, 414 pp. http:// www.anemoon.org/flora-en-fauna/soorteninformatie/ soorten/id/484/gouden-tapijtschelp

Catuneanu, O., Galloway, W.E., Kendall, C.G.St.C., Miall, A.D., Posamentier, H.W., Strasser, A. and Tucker, M.E., 2011. Sequence Stratigraphy: methodology and nomenclature. Newsletters on Stratigraphy, 44, 173-245. https://doi.org/10.1127/0078-0421/2011/0011

Cernajsek, T., 1974. Die Ostracodenfaunen der Sarmatischen Schichten in Österreich. In: A. Papp, F. Marinescu and J. Seneš (eds.), Chronostratigraphie und Neostratotypen, Miozän der Zentralen Paratethys. Verlag der Slowakischen Akademie der Wissenschaften, Bratislava, 4 (M5), pp. 458-491.

Cicha, I., Rögl, F., Rupp, C. and Ctyroky, J., 1998. Oligocene-Miocene foraminifera of the Central Paratethys. Abhandlungen der Senckenbergischen Naturforschenden Gesellschaft, 549, 1-325.

Čtyroký, P., 2000. Nové litostratigafické jednotky pannonu vídeňské pánve na Moravě. Věstník Českého geologického ústavu, 75, 159-170.

Cziczer I., Magyar I., Pipík R., Böhme M., Ćorić S., Bakrač K., Sütő-Szentai M., Lantos M., Babinszki E. and Müller P., 2009. Life in the sublittoral zone of long-lived Lake Pannon: paleontological analysis of the Upper Miocene Szák Formation, Hungary. International Journal of Earth Science, 98, 1741-1766. https://doi.org/10.1007/ s00531-008-0322-3

Deutzmann, J.S. and Schink, B., 2011. Anaerobic oxidation of methane in sediments of Lake Constance, an oligotrophic freshwater lake. Applied Environmental Microbiology, 77, 4429-4436. https://doi.org 10.1128/ AEM.00340-11

Egger, M., Rasigraf, O., Sapart, C.J., Jilbert, T., Jetten, M.S.M., Röckmann, T., van der Veen, C., Bândă, N., Kartal, B., Ettwig, K.F., Slomp, C.P., 2015. Iron-mediated anaerobic oxidation of methane in brackish coastal sediments. Environmental Science and Technology, 49, 277-283. http://pubs.acs.org/doi/abs/10.1021/es503663z

Elečko, M. and Vass, D., 2001. Litostratigrafické jednotky usadenín sarmatského veku vo viedenskej panve. Mineralia Slovaca, 33, 1-6.

Faegri, K. and Iversen, J., 1989. Textbook of Pollen Analysis, $4^{\text {th }}$ Edition. Wiley, Chichester, $328 \mathrm{pp}$.

Filipescu, S. and Popa, M., 2001. Biostratigraphic and palaeoecologic significance of the macro- and microfossils assemblages in the Borod Formation (Eastern Borod Depression, North-West Romania). Acta Palaeontologica Romaniae, 3, 135-148.

Filipescu, S., Wanek, F., Miclea, A., De Leeuw, A. and Vasiliev, I., 2011. Micropaleontological response to the changing paleoenvironment across the Sarmatian-Pannonian boundary in the Transylvanian Basin (Miocene, Oarba de Mure section, Romania). Geologica Carpathica, 62, 91-102. https://doi.org/10.2478/v10096-011-0008-9 Fuchs, W., 1985. Österreichische Geologische Karte 59, Wien 1:50.000. Geologische Bundesanstalt, Wien.

Geary, D.H., Hunt, G., Magyar, I. and Schreiber, H., 2010. The paradox of gradualism: phyletic evolution in two lineages of lymnocardiid bivalves (Lake Pannon, central Europe). Paleobiology, 36, 592-614. https://doi. org/10.1666/08065.1

Geary, D.H., Rich, J.A., Valley, J.W. and Baker, K., 1989. Stable isotopic evidence of salinity change: influence 
on the evolution of melanopsid gastropods in the Late Miocene Pannonian basin. Geology, 17, 981-985. https://doi.org/10.1130/0091-7613(1989)017<0981:SIE OSC $>2.3 . \mathrm{CO} ; 2$

Gofas, S. Moreno, D. and Salas, C., 2011. Moluscos marinos de Andalucía. Universidad de Málaga, Málaga. 2 volumes, $798 \mathrm{pp}$.

Gross, M., 2004. Zur Ostracodenfauna (Crustacea), Paläoökologie und Stratigrafie der Tongrube Mataschen (Unter-Pannonium, Steirisches Becken, Österreich). Joannea Geologie und Paläontologie, 5, 49-129.

Gross, M., 2006. Mittelmiozäne Ostracoden aus dem Wiener Becken (Badenium/Sarmatium, Österreich). Österreichische Akademie der Wissenschaften, Schriftenreihe der Erdwissenschaftlichen Kommissionen, Sonderband 1, 1-224. ISBN 978-3-7001-3650-7

Gross, M., Piller, W.E., Scholger, R. and Gitter, F., 2011. Biotic and abiotic response to palaeoenvironmental changes at Lake Pannons' western margin (Central Europe, Late Miocene). Palaeogeography, Palaeoclimatology, Palaeoecology, 312, 181-193. https://doi.org/10.1016/j. palaeo.2011.10.010

Hammer, Ø. and Harper, D.A.T., 2006. Paleontological Data Analysis. Blackwell Publishing, Oxford, 351 pp.

Hammer, Ø., Harper, D.A.T. and Ryan, P.D., 2001. PAST: paleontological statistics software package for education and data analysis. Palaeontologia Electronica, 4, 1-9.

Harzhauser, M., 2009. The early Vallesian vertebrates of Atzelsdorf (Late Miocene, Austria). 2. Geology. Annalen des Naturhistorischen Museums in Wien, 111A, 479-488.

Harzhauser, M. and Piller, W.E., 2004. The Early Sarmatian hidden seesaw changes. Courier des Forschungsinstitutes Senckenberg, 246, 89-112.

Harzhauser, M., Piller, W.E., 2007. Benchmark data of a changing sea. - Palaeogeography, Palaeobiogeography and Events in the Central Paratethys during the Miocene. Palaeogeography, Palaeoclimatology, Palaeoecology, 253, 8-31. https://doi.org/10.1016/j.palaeo.2007.03.031

Harzhauser, M. and Piller, W.E., 2010. Molluscs as a major part of subtropical shallow-water carbonate productionan example from a Middle Miocene oolite shoal (Upper Serravallian, Austria). International Association of Sedimentologists, Special Publications, 42, 185-200. https:// doi.org/10.1002/9781118398364.ch11

Harzhauser, M., Daxner-Höck, G. and Piller, W.E., 2004. An integrated stratigraphy of the Pannonian (Late Miocene) in the Vienna Basin. Austrian Journal of Earth Science, 95/96, 6-19.

Harzhauser, M., Kowalke, T. and Mandic, O., 2002. Late Miocene (Pannonian) gastropods of Lake Pannon with special emphasis on early ontogenetic development. Annalen des Naturhistorischen Museums Wien, 103A, 75-141.

Harzhauser, M., Latal, C. and Piller, W.E., 2007. The stable isotope archive of Lake Pannon as a mirror of Late Miocene climate change. Palaeogeography, Palaeoclimatology, Palaeoecology, 249, 335-350. https://doi org/10.1016/j.palaeo.2007.02.006
Harzhauser, M., Kern, A., Soliman, A., Minati, K., Piller, W.E., Danielopol, D.L. and Zuschin, M., 2008. Centennial- to decadal scale environmental shifts in and around Lake Pannon (Vienna Basin) related to a major Lake Miocene lake level rise. Palaeogeography, Palaeoclimatology, Palaeoecology, 270, 102-115. https://doi.org/10.1016/j. palaeo.2008.09.003

Hölzel, M., Wagreich, M., Faber, R. and Strauss, P., 2008. Regional subsidence analysis of the Vienna Basin (Austria). Austrian Journal of Earth Sciences, 101, 88-98. Hopkins, J.S., 1950. Differential flotation and deposition of coniferous and deciduous tree pollen. Ecology, 31, 633-641. https://doi.org/10.2307/1931580

Hyžný, M., Šimo, V. and Starek, D., 2015. Ghost shrimps (Decapoda: Axiidea: Callianassidae) as producers of an Upper Miocene trace fossil association from sublittoral deposits of Lake Pannon (Vienna Basin, Slovakia). Palaeogeography, Palaeoclimatology, Palaeoecology, 425, 50-66. https://doi.org/10.1016/j.palaeo.2015.02.012

Jekelius, E., 1944. Sarmat und Pont von Soceni (Banat). Memoriile Institutului Geolologic al României, 5, 1-167. Jiménez-Moreno, G., Fauquette, S. and Suc, J.-P., 2008. Vegetation, climate and paleoaltitude reconstructions of eastern alpine mountain ranges during the Miocene based on pollen records from Austria, Central Europe. Journal of Biogeography, 35, 1638-1649. http://onlinelibrary.wiley.com/ doi/10.1111/j.1365-2699.2008.01911.x/epdf

Jiříček, R., 1974. Biostratigraphische Bedeutung der Ostracoden des Sarmats s. str. In: A. Papp, F. Marinescu and J. Seneš (eds.), Chronostratigraphie und Neostratotypen, Miozän der Zentralen Paratethys. Verlag der Slowakischen Akademie der Wissenschaften, Bratislava, 4 (M5), pp. 434-457.

Jiř́čcek, R., 1985. Die Ostracoden des Pannonien. In: A. Papp, A. Jámbor and F.F. Steininger (eds.), Chronostratigraphie und Neostratotypen, Miozän der Zentralen Paratethys. Ungarische Akademie der Wissenschaften, Budapest, 7 (M6), pp. 378-425.

Jiříček, R. and Riha, J., 1991. Correlation of Ostracod Zones in the Paratethys and Tethys. Saito Ho-on Kai Special Publications (Proceedings of Shallow Tethys), 3, 435-457.

Karrer, F., 1877. Geologie der Kaiser Franz Josefs Hochquellen-Wasserleitung: Eine Studie in den TertiärBildungen am Westrande des Alpinen Theiles der Niederung von Wien. Abhandlungen der k.k. Geologischen Reichsanstalt, 9, 1-410.

Kern, A.K., Harzhauser, M., Piller, W.E., Mandic, O. and Soliman, A., 2012a. Strong evidence for the influence of solar cycles on a Late Miocene lake system revealed by biotic and abiotic proxies. Palaeogeography, Palaeoclimatology, Palaeoecology, 329-330, 124-136. https:// doi.org/10.1016/j.palaeo.2012.02.023

Kern, A.K., Harzhauser, M., Soliman, A., Piller, W.E. and Gross, M., 2012b. Precipitation driven decadal scale decline and recovery of wetlands of Lake Pannon during the Tortonian. Palaeogeography, Palaeoclimatology, 
Palaeoecology,317-318,1-12.https://doi.org/10.1016/j. palaeo.2011.11.021

Kern, A.K., Harzhauser, M., Soliman, A., Piller, W.E., Mandic, O., 2013. High resolution analysis of Upper Miocene lake deposits: Evidence for the influence of Gleissberg-band-solar forcing. Palaeogeography, Palaeoclimatology, Palaeoecology, 370, 167-183. http://dx. doi.org/10.1016/j.palaeo.2012.12.005

Klaus, W. 1984. Zur Mikroflora des Unter-Sarmat am Alpen-Südostrand. Beiträge zur Paläontologie von Österreich, 11, 289-419.

Kollmann, K., 1960. Cytherideinae und Schulerideinae n. subfam. (Ostracoda) aus dem Neogen des östl. Oesterreich. Mitteilungen der Geologischen Gesellschaft in Wien, 51, 89-195.

Kováč, M., Baráth, I., Kováčova-Slamková, M., Pipík, R., Hlavatý, I., Hudáčková, N., 1998. Late Miocene paleoenvironments and sequence stratigraphy: northern Vienna Basin. Geologica Carpathica, 49, 445-458.

Krenmayr, H.G. and Schnabel, W., 2002. Intramontane Becken (T6-T7). In: Schnabel, W. (Ed.): Geologische Karte von Niederösterreich 1: 200.000. Legende und kurze Erläuterung, Geologische Bundesanstalt, Wien, pp. 30-33.

Kröll, A. and Wessely, G., 1993. Wiener Becken und angrenzende Gebiete - Strukturkarte-Basis der tertiären Beckenfüllung. Geologische Themenkarte der Republik Österreich 1:200.000, Geologische Bundesanstalt, Wien.

Krstić, N., 1985. Ostracoden im Pannonien der Umgebung von Belgrad. In: A. Papp, A. Jámbor and F.F. Steininger (eds.), Chronostratigraphie und Neostratotypen, Miozän der Zentralen Paratethys. Ungarische Akademie der Wissenschaften, Budapest, 7 (M6), pp. 103-143.

Langer, M.R., 1993. Epiphytic foraminifera. Marine Micropaleontology, 20, 235-265. https://doi. org/10.1016/0377-8398(93)90035-V

Latal, C., Piller, W.E. and Harzhauser, M., 2006. Shifts in oxygen and carbon isotope signals in marine molluscs from the Central Paratethys (Europe) around the Lower/ Middle Miocene transition. Palaeogeography, Palaeoclimatology, Palaeoecology, 231, 347-360. https://doi. org/10.1016/j.palaeo.2005.08.008

Lee, E.Y. and Wagreich, M., 2016. Polyphase tectonic subsidence evolution of the Vienna Basin inferred from quantitative subsidence analysis of the northern and central parts. International Journal of Earth Sciences, 106, 687-705. https://doi.org/10.1007/s00531-016-1329-9

Lin, Z., Sun, X., Lu, Y. and Lu, H., 2014. Heavy sulfur isotopic composition of authigenic pyrite in the sediments of Shenhu area, South China Sea. Acta Geologica Sinica, 88, Supplementum 2, 1569-1570. https://doi. org/10.1111/1755-6724.12384_9

Lin, Z., Sun, X., Peckmann, J., Lu, Y., Xu, L., Strauss, H., Zhou, H., Gong, J., Lu, H. and Teichert, B.M.A., 2016. How sulfate-driven anaerobic oxidation of methane affects the sulfur isotopic composition of pyrite: A SIMS study from the South China Sea. Chemical Geology, 440, 26-41. https://doi.org/10.1016/j.chemgeo.2016.07.007
Lirer, F., Harzhauser, M., Pelosi, N., Piller, W.E., Schmid, H.P. and Sprovieri, M., 2009. Astronomically forced teleconnection between Paratethyan and Mediterranean sediments during the Middle and Late Miocene Palaeogeography, Palaeoclimatology, Palaeoecology, 275, 1-13. https://doi.org/10.1016/j.palaeo.2009.01.006

Lodge, T.E., 2016. The Everglades Handbook Understanding the Ecosystem. Taylor and Francis Group, Boca Raton, $4^{\text {th }}$ Edition, $432 \mathrm{pp}$.

Lozouet, P., Lesport, J.F., and Renard, P., 2001. Révision des Gastropoda (Mollusca) du Stratotype de l'Aquitanien (Miocène inf.): site de Saucats "Lariey", Gironde, France. Cossmanniana, Hors série, 3, 1-189.

Lu, H.F., Chen, F., Liao, Z.L., Sun, X.M., Liu, J., Cheng, S.H. and $\mathrm{Fu}$, S.Y., 2007. Authigenic pyrite rods from the core HD196A in the northeastern South China Sea. Acta Geologica Sinica, 81, 519-525 (in Chinese).

Lukeneder, S., Zuschin, M., Harzhauser, M. and Mandic, O., 2011. Spatiotemporal signals and palaeoenvironments of endemic molluscan assemblages in the marine system of the Sarmatian Paratethys. Acta Palaeontologica Polonica, 56/4, 767-784. https://doi.org/10.4202/ app.2010.0046

Magyar, I., Geary, D.H. and Müller, P., 1999. Paleogeographic evolution of the Late Miocene Lake Pannon in Central Europe. Palaeogeography, Palaeoclimatology, Palaeoecology, 147, 151-167. https://doi.org/10.1016/ S0031-0182(98)00155-2

Magyar I., Müller P.M., Sztanó O., Babinszki E. and Lantos M., 2006. Oxygen-related facies in Lake Pannon deposits (Upper Miocene) at Budapest-Köbánya. Facies, 52, 209-220. https://doi.org/10.1007/s10347-005-0036-y

Magyar, I., Cziczer, I., Stanó, O., Dávid, Á. and Johnson, M., 2016. Palaeobiology, palaeoecology and stratigraphic significance of the Late Miocene cockle Lymnocardium soproniense from Lake Pannon. Geologica Carpathica, 67, 561-571. https://doi.org/10.1515/ geoca-2016-0035

Maslo, M., 2015. Geologisch-paläontologische Untersuchung U2-Verlängerung/U5-Neubau. Unpublished report MA 29, Vienna, 58 pp.

Mátyás, J., Burns, S.J., Müller, P. and Magyar, I., 1996. What can stable isotopes say about salinity? An example from the Late Miocene Pannonian Lake. Palaios, 11, 31-39. https://doi.org/10.2307/3515114

McGlynn, S.E., Chadwick, G.L., Kempes, C.P. and Orphan, V.J., 2015. Single cell activity reveals direct electron transfer in methanotrophic consortia. Nature, 526, 531-535. https://doi.org/10.1038/nature15512

Mosbrugger, V. and Utescher, T., 1997. The coexistence approach - a method for quantitative reconstructions of Tertiary terrestrial palaeoclimate data using plant fossils. Paleogeography, Palaeoclimatology, Palaeoecology, 134, 61-86. https://doi.org/10.1016/ S0031-0182(96)00154-X

Murray, J.W., 2006. Ecology and applications of benthic foraminifera. Cambridge University Press, Cambridge, $426 \mathrm{pp}$. 
Neubauer, T.A., Harzhauser, M. and Mandic, O., $2013 a$. Phenotypic evolution in a venerid bivalve species lineage from the late Middle Miocene Central Paratethys Sea: a multi-approach morphometric analysis. Biological Journal of the Linnean Society, 110, 320-334. https:// doi.org/10.1111/bij.12120

Neubauer, T.A., Harzhauser, M. and Kroh, A., 2013b. Phenotypic evolution in a fossil gastropod species lineage: evidence for adaptive radiation? Palaeogeography, Palaeoclimatology, Palaeoecology, 370, 117-126.

Neubauer, T.A., Harzhauser, M., Mandic, O Kroh, A. and Georgopoulou, E., 2016. Evolution, turnovers and spatial variation of the gastropod fauna of the late Miocene biodiversity hotspot Lake Pannon. Palaeogeography, Palaeoclimatology, Palaeoecology, 442, 84-95. https:// doi.org/10.1016/j.palaeo.2012.11.025

Oliver, P.G., Holmes, A.M., Killeen, I. J. and Turner, J.A., 2016. Marine bivalve shells of the British Isles. Amgueddfa Cymru - National Museum Wales. http://naturalhistory.museumwales.ac.uk/britishbivalves. [Accessed: 13 October 2017].

Olteanu, R., 1989. New ostracods in upper Neogene from Romania. Institut de Géologie et de Géophysique Bucarest, Mémoires, 34, 123-182.

Papp, A., 1951. Das Pannon des Wiener Beckens. Mitteilungen der Geologischen Gesellschaft in Wien, 39-41 (1946-1948), 99-193.

Papp, A., 1953. Die Molluskenfauna des Pannon des Wiener Beckens. Mitteilungen der Geologischen Gesellschaft in Wien, 44, 85-222.

Papp, A., 1954. Die Molluskenfauna im Sarmat des Wiener Beckens. Mitteilungen der Geologischen Gesellschaft in Wien, 45, 1-112.

Papp, A., 1956. Fazies und Gliederung des Sarmats im Wiener Becken. Mitteilungen der Geologischen Gesellschaft in Wien, 47 (1954), 1-97.

Papp, A., Marinescu, F. and Senes, J., 1974 (eds), M5. Sarmatien. Chronostratigraphie und Neostratotypen, 4, 1-707, VEDA, Bratislava.

Paulissen, W.E., Luthi, S.M., Grunert, P., Ćorić, S. and Harzhauser, M., 2011. Integrated high-resolution stratigraphy of a Middle to Late Miocene sedimentary sequence in the central part of the Vienna Basin. Geologica Carpathica, 62, 155-169. https://doi.org/10.2478/ v10096-011-0013-z

Planderova, E., 1990. Miocene microflora of Slovak Central Paratethys and its biostratigraphic significance. Dionyz Stur Institute of Geology, Bratislava, 144 pp.

Rao, V.P., Kessarkar, P.M., Patil, S.K. and Ahmad, S.M., 2008. Rock magnetic and geochemical record in a sediment core from the eastern Arabian Sea: diagenetic and environmental implications during the late Quaternary. Palaeogeography, Palaeoclimatology, Palaeoecology, 270, 46-52. https://doi.org/10.1016/j. palaeo.2008.08.011

de Rigo, D., Caudullo, G., Houston Durrant, T. and SanMiguel-Ayanz, J., 2016. The European Atlas of Forest Tree Species: modelling, data and information on forest tree species. In: San-Miguel-Ayanz, J., de Rigo, D., Caudullo, G., Houston Durrant, T., Mauri, A. (Eds.): European Atlas of Forest Tree Species. Publ. Off. EU, Luxembourg, pp. e01aa69+. https://w3id.org/mtv/FISE-Comm/v01/ e01aa69

Rögl, F., 1998. Foraminiferenfauna aus dem Karpat (UnterMiozän) des Korneuburger Beckens. Beiträge zur Paläontologie, 23, 123-173.

Sassen, R., Roberts, H.H., Carney, R., Milkov, A.V., DeFreitas, D.A., Lanoil, B. and Zhang, C., 2004. Free hydrocarbon gas, gas hydrate, and authigenic minerals in chemosynthetic communities of the northern Gulf of Mexico continental slope: relation to microbial processes. Chemical Geology, 205, 195-217. https://doi.org/10.1016/j. chemgeo.2003.12.032

Schaffer, F.X., 1906. Geologie von Wien. II. Theil. R. Lechner, Wien, 242 pp.

Schnabel, W., Krenmayr, H.-G., Mandl, G.W., Nowotny, A., Roetzel, R. and Scharbert, S., 2002. Legende und kurze Erläuterungen zur geologischen Karte von Niederösterreich 1:200.000. Geologische Bundesanstalt Wien, 47 pp. Schultz, O., 2003. Bivalvia neogenica (LucinoideaMactroidea). In: Piller, W.E. (ed.), Catalogus Fossilium Austriae. Verlag ÖAW, Wien, pp. 381-690.

Schwarzhans, W., Carnevale, G., Bratishko, A., Japundžić, S. and Bradić, K., 2017a. Otoliths in situ from Sarmatian (Middle Miocene) fishes of the Paratethys. Part II: Gadidae and Lotidae. Swiss Journal of Palaeontology, 136, 19-43. https://doi.org/10.1007/s13358-016-0114-5

Schwarzhans, W., Ahnelt, H., Carnevale, G., Japundžić, S., Bradić, K. and Bratishko, A., 2017b. Otoliths in situ from Sarmatian (Middle Miocene) fishes of the Paratethys. Part III: Tales from the cradle of the PontoCaspian gobies. Swiss Journal of Palaeontology, 136, 45-92. https://doi.org/10.1007/s13358-016-0120-7

Smirnov, A., Chmura, G.L. and Lapointe, M.F., 1996. Spatial distribution of suspended pollen in the Mississippi River as an example of pollen transport in alluvial channels. Review of Palaeobotany and Palynology, 92, 69-81. https://doi.org/10.1016/0034-6667(95)00098-4

Stuchlik, L., Ziembińska-Tworzydło, M., KohlmanAdamska, A., Grabowska, I., Ważyńska, H., Słodkowska, B. and Sadowska, A., 2001. Atlas of pollen and spores from the Polish Neogene, Vol. 1, spores. Polish Academy of Sciences, W Szafer Institute of Botany, Kraków, 158 pp. Stuchlik, L., Ziembińska-Tworzydło, M., KohlmanAdamska, A., Grabowska, I., Ważyńska, H. and Sadowska, A., 2002. Atlas of pollen and spores from the Polish Neogene, Vol. 2, gymnosperms. Polish Academy of Sciences, W Szafer Institute of Botany, Kraków, 237 pp.

Stuchlik, L., Ziembińska-Tworzydło, M., KohlmanAdamska, A., Grabowska, I., Ważyńska, H. and Sadowska, A., 2009. Atlas of pollen and spores from the Polish Neogene, Vol. 3, Angiosperm (1). Polish Academy of Sciences, W Szafer Institute of Botany, Kraków, 233 pp.

Stuchlik, L., Ziembińska-Tworzydło, M., KohlmanAdamska, A., Grabowska, I., Ważyńska, H. and Sadowska, A., Durska, E., 2014. Atlas of pollen and spores from the 
Polish Neogene, Vol. 4, Angiosperm (2). Polish Academy of Sciences, W Szafer Institute of Botany, Kraków, 466 pp. Suess, E., 1866. Untersuchungen über den Charakter der österreichischen Tertiärablagerungen, II. Über die Bedeutung der sogenannten brackischen Stufe oder der Cerithienschichten. Sitzungsberichte der k. Akademie der Wissenschaften, 54, 1-40.

Sztanó, O., Krézsek, C., Magyar, I., Wanek, F., and Juhász, G., 2005. Sedimentary cycles and rhythms in a Sarmatian to Pannonian (Late Miocene) transitional section at Oarba de Mures/Marosorbó, Transylvanian Basin. Acta Geologica Hungarica, 48, 235-257. https://doi.org/10.1556/ AGeol.48.2005.3.1

Starek, D. and Pipík, R., 2007. Oxic and ?anoxic deposits of the Pannonian E (Late Miocene) from the Vienna Basin (sedimentological and micropaleontological description of sediments with Congeria subglobosa horizon. Scripta Facultatis scientiarum naturalium Universitatis Masarykiane Brunensis, 36, 25-30.

Tauber, A.F., 1939a. Ein Aufschluß an der Grenze zwischen Sarmat und Pannon im XVII. Wiener Gemeindebezirk. Verhandlungen der Zweigstelle Wien der Reichsstelle für Bodenforschung, 1939, 205-209.

Tauber, A.F., 1939b. Studien im Sarmat und Pannon des Küniglberg - Gloriettenbergzuges in Wien. Verhandlungen der Zweigstelle Wien der Reichsstelle für Bodenforschung, 1939, 161-183.

Thompson, R.S., Anderson, K.H. and Bartlein, P.J., 1999a. Atlas of relations between climatic parameters and distributions of important trees and shrubs in North America - Introduction and conifers: U.S. Geological Survey Professional Paper, 1650A, 269 pp.

Thompson, R.S., Anderson, K.H. and Bartlein, P.J., $1999 \mathrm{~b}$. Atlas of relations between climatic parameters and distributions of important trees and shrubs in North America - Hardwoods: U.S. Geological Survey Professional Paper, 1650B, 423 pp.

Tóth, E., 2008. Sarmatian (Middle Miocene) ostracod fauna from the Zsámbek Basin, Hungary. Geologica Pannonica, 36, 101-151.

Traverse, A. and Ginsburg, R.N., 1966. Palynology of the surface sedimentation of Great Bahamas Bank, as related to water movements and sedimentation. Marine Geology, 4, 417-459. https://doi. org/10.1016/0025-3227(66)90010-7

Utescher, T., Bruch, A.A., Erdei, B., François, L., Ivanov, D., Jacques, F.M.B., Kern, A.K., Liu, Y.-S., Mosbrugger, V. and Spicer, R.A., 2014. The Coexistence Approach-Theoretical background and practical considerations of using plant fossils for climate quantification. Palaeogeography, Palaeoclimatology, Palaeoecology, 410, 58-73. https://doi.org/10.1016/j.palaeo.2014.05.031

Vasiliev, I., de Leeuw, A., Filipescu, S., Krijgsman, W., Kuiper, K., Stoica, M. and Briceag, A., 2010. The age of the Sarmatian-Pannonian transition in the Transylvanian Basin (Central Paratethys). Palaeogeography, Palaeoclimatology, Palaeoecology, 297, 54-69. https://doi. org/10.1016/j.palaeo.2010.07.015
Walton, W.R. and Sloan, B.J., 1990. The genus Ammonia Brunnich, 1772. Its geographic distribution and morphologic variability. Journal of Foraminiferal Research, 20, 128-156. https://doi.org/10.2113/gsjfr.20.2.128

Wegener, G., Krukenberg, V., Riedel, D., Tegetmeyer, H.E. and Boetius, A., 2015. Intercellular wiring enables electron transfer between methanotrophic archaea and bacteria. Nature 526, 587-590. https://doi.org/10.1038/ nature15733

Welter-Schultes, F., 2012. European non-marine molluscs, a guide for species identification. Planet Poster Editions, Göttingen, 674 pp.

Wessely, G., 2006. Niederösterreich. Geologie der Österreichischen Bundesländer. Geologische Bundesanstalt Wien, $416 \mathrm{pp}$.

Wilen, B.O. and Tiner, R.W., 1993. Wetlands of the United States. In: Whigham, D.F., Dykyjová, D., Hejný, S. (Eds.): Handbook of Vegetation Science, Wetlands of the World I: Inventory, Ecology and Management. Kluwer Academic Publishers, Dordrecht, Bosten, London, pp. 129-194.

Willard, D.A., Weimer, L.M. and Riegel, W.L., 2001. Pollen assemblages as paleoenvironmental proxies in the Florida Everglades. Review of Palaeobotany and Palynology, 113, 213-235. https://doi.org/10.1016/ S0034-6667(00)00042-7

Wilson, B., 1998. Superfamily Cardioidea. In: Beesley, P.L., Ross, G.J.B. and Wells, A. (eds.), Mollusca. The Southern Synthesis: Fauna of Australia, Part A, 5, 328-332.

Wu, Z., Zhou, H., Peng, X., Jia, N., Wang, Y. and Yuan, L., 2009. Anaerobic oxidation of methane in coastal sediment from Guishan Island (Pearl River Estuary), South China Sea. Journal of Earth System Science, 117, 935-943. https://doi.org/10.1007/s12040-008-0078-y

Xie, L., Wang, J.S., Wu, N.Y., Wu, D.D., Wang, Z., Zhu, X.W., Hu, J., Chen, H.R. and Lin, Q., 2013. Characteristics of authigenic pyrites in shallow core sediments in the Shenhu area of the northern South China Sea: Implications for a possible mud volcano environment. Science China Earth Science, 56, 1-7. https://doi.org/10.1007/ s11430-012-4511-3

Zelenka, J., 1990. A review of the Sarmatian Ostracoda of the Vienna Basin. In: R. Whatley and C. Maybury (eds.), Ostracoda and Global Events. Chapman \& Hall, London, pp. 263-270.

Zelenka, J., 1992. A review of the Pannonian Ostracoda of the Vienna Basin. Knihovnicka Zemniho plynu a nafty, 15, 205-213.

Zhang. M., Konishi, H., Xu, H., Sun, X., Lu, H., Wu, D. and $\mathrm{Wu}, \mathrm{N} ., 2014$. Morphology and formation mechanism of pyrite induced by the anaerobic oxidation of methane from the continental slope of the NE South China Sea. Journal of Asian Earth Sciences, 92, 293-301. https:// doi.org/10.1016/j.jseaes.2014.05.004

Zuschin, M. and Oliver, P.G., 2003. Bivalves and bivalve habitats in the northern Red Sea. Verlag des Naturhistorischen Museums, Wien, 304 pp., ISBN: 3902421002 
Mathias HARZHAUSER ${ }^{1 *}$, Oleg MANDIC ${ }^{1)}$, Matthias KRANNER ${ }^{1)}$, Petra LUKENEDER ${ }^{1)}$, Andrea K. KERN ${ }^{2}$, Martin Gross $^{3)}$, Giorgio (ARNEVALE ${ }^{4)}$ \& Christine JAWECKI)

1) Geological-Paleontological Department, Natural History Museum Vienna, Burgring 7, 1010 Vienna, Austria; mathias.harzhauser@nhmwien.ac.at; oleg.mandic@nhm-wien.ac.at; petra.lukeneder@gmx.at;

2) Department of Sedimentary and Environmental Geology, University of São Paulo, Rua do Lago 562, São Paulo 05508-080, Brazil; annkkern@ usp.br;

3) Universalmuseum Joanneum, Department for Geology \& Palaeontology, Weinzöttlstraße 16, 8045 Graz, Austria; martin.gross@museum-joanneum.at;

4) Università degli Studi di Torino, Dipartimento di Scienze della Terra, Via Valperga Caluso, 35, 10125 Torino, Italy; giorgio.carnevale@unito.it; 5) Magistratsabteilung 29, Brückenbau und Grundbau, Wilhelminenstraße 93, 1160 Vienna, Austria; christine.jawecki@wien.gv.at;

*) Corresponding author: mathias.harzhauser@nhm-wien.ac.at 


\section{ONLINE APPENDIX}

\begin{tabular}{|c|c|c|c|c|c|c|c|c|c|c|c|c|c|c|c|c|c|}
\hline \multirow{3}{*}{\begin{tabular}{|l}
$\mid$ \\
Taxa (\%)
\end{tabular}} & 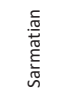 & 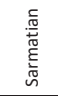 & 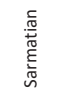 & 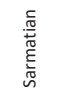 & 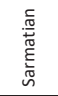 & 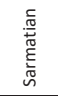 & 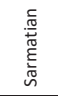 & 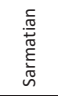 & 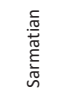 & 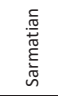 & 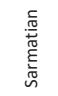 & 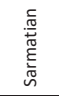 & 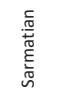 & 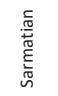 & 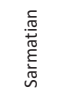 & 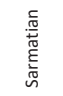 & 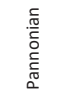 \\
\hline & 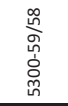 & 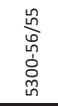 & 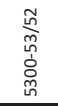 & 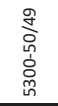 & 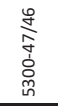 & 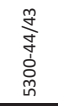 & 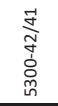 & 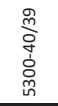 & $\begin{array}{l}\hat{m} \\
\infty \\
\infty \\
\tilde{\delta} \\
\dot{ల} \\
n\end{array}$ & 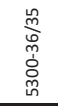 & 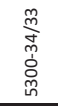 & 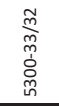 & $\begin{array}{l}\vec{m} \\
\stackrel{n}{n} \\
\text { రे } \\
\text { nn }\end{array}$ & 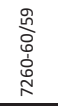 & 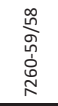 & 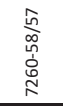 & 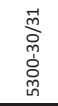 \\
\hline & 0.00 & 0.00 & 0.00 & 0.00 & 0.00 & 0.00 & 0.00 & 0.00 & 0.00 & 0.00 & 0.00 & 0.00 & 0.00 & 0.00 & 0.00 & 0.00 & 0.00 \\
\hline Ammonia beccari i (Linnaeus, 1758) & 0.00 & 1.24 & 0.00 & 0.00 & 0.87 & 11.48 & 10.19 & 0.00 & 9.30 & 0.00 & 0.00 & 15.52 & 15.76 & 0.37 & 0.27 & 0.00 & 0.00 \\
\hline Ammonia cf. tepida (Cushman, 1926) & 0.00 & 0.00 & 0.00 & 0.00 & 0.00 & 0.00 & 0.00 & 0.00 & 0.00 & 0.00 & 0.00 & 0.00 & 0.00 & 0.37 & 0.00 & 0.00 & 0.00 \\
\hline Ammonia sp. & 0.00 & 0.00 & 0.00 & 0.00 & 0.00 & 0.00 & 0.00 & 0.00 & 0.00 & 0.00 & 0.00 & 0.00 & 0.00 & 0.00 & 0.00 & 0.00 & 0.00 \\
\hline Anomalinoides ?sp. & 0.00 & 0.00 & 0.00 & 0.00 & 0.00 & 0.00 & 0.00 & 0.00 & 0.00 & 0.00 & 0.00 & 0.00 & 0.00 & 0.00 & 0.27 & 1.07 & 0.00 \\
\hline Articulina problema Bogdanowicz, 1952 & 0.00 & 0.00 & 0.00 & 0.00 & 0.00 & 0.00 & 0.00 & 0.00 & 0.00 & 0.00 & 0.56 & 0.00 & 0.00 & 0.00 & 0.27 & 0.00 & 0.00 \\
\hline Aubignyna sp. & 0.00 & 0.00 & 0.00 & 0.00 & 0.00 & 0.00 & 0.00 & 0.00 & 0.00 & 0.00 & 0.00 & 0.00 & 0.00 & 0.00 & 0.00 & 0.00 & 0.00 \\
\hline Bolivina sarmatica Didkowski, 1959 & 0.00 & 0.00 & 0.00 & 0.00 & 0.00 & 17.37 & 0.00 & 0.00 & 0.00 & 0.00 & 0.00 & 0.00 & 2.25 & 0.74 & 0.00 & 0.00 & 0.00 \\
\hline Brizalina sp. & 0.00 & 0.00 & 0.00 & 0.00 & 0.00 & 0.00 & 0.00 & 0.00 & 0.00 & 0.00 & 0.00 & 0.00 & 0.00 & 1.84 & 0.00 & 0.00 & 0.00 \\
\hline Bulimina elongata d'Orbigny, 1826 & 0.00 & 0.00 & 0.00 & 0.00 & 0.29 & 1.68 & 0.00 & 0.00 & 1.33 & 0.00 & 0.00 & 0.76 & 0.32 & 2.94 & 0.00 & 0.00 & 0.00 \\
\hline Bulimina sp. & 0.00 & 0.00 & 0.00 & 0.00 & 0.00 & 0.00 & 0.00 & 0.00 & 0.00 & 0.00 & 0.00 & 0.00 & 1.29 & 9.93 & 0.00 & 0.00 & 0.00 \\
\hline Ceratocancris haueri (d"Orbigny, 1846) & 0.00 & 0.00 & 0.00 & 0.00 & 0.00 & 0.00 & 0.00 & 0.00 & 0.00 & 0.00 & 0.00 & 0.00 & 0.00 & 0.37 & 0.00 & 0.00 & 0.00 \\
\hline Cibicidoides sp. & 0.00 & 0.00 & 0.00 & 0.00 & 0.00 & 0.00 & 0.00 & 0.00 & 0.00 & 0.00 & 0.00 & 0.00 & 0.00 & 0.00 & 0.00 & 1.34 & 0.00 \\
\hline Cycloforina badenensis (d'Orbigny, 1846) & 0.00 & 1.24 & 1.51 & 0.87 & 0.00 & 2.24 & 0.00 & 0.00 & 0.00 & 0.00 & 0.00 & 0.00 & 0.00 & 0.37 & 0.00 & 0.27 & 0.00 \\
\hline Cycloforina contorta (d'Orbigny, 1846) & 0.00 & 0.00 & 0.00 & 0.00 & 0.00 & 0.00 & 0.00 & 0.00 & 0.00 & 0.00 & 0.84 & 0.00 & 0.00 & 0.37 & 0.00 & 0.00 & 0.00 \\
\hline Cycloforina fluvia ta (Venglinski, 1958) & 2.19 & 0.41 & 0.00 & 0.00 & 0.00 & 12.32 & 3.18 & 0.00 & 9.30 & 0.50 & 4.49 & 3.82 & 4.82 & 0.37 & 1.61 & 0.27 & 0.00 \\
\hline Cycloforina haueriana (d'Orbigny, 1846) & 0.00 & 0.00 & 0.00 & 0.00 & 0.00 & 0.00 & 0.00 & 0.00 & 0.00 & 0.00 & 0.00 & 0.00 & 0.00 & 4.78 & 0.00 & 0.00 & 0.00 \\
\hline Cycloforina karreri ovat a (Serova, 1955) & 0.31 & 0.00 & 0.30 & 0.29 & 0.00 & 0.00 & 0.64 & 0.00 & 0.00 & 0.00 & 0.28 & 0.00 & 0.00 & 0.00 & 0.00 & 0.00 & 0.00 \\
\hline Cycloforina sp. & 0.00 & 0.00 & 0.00 & 0.00 & 0.29 & 0.00 & 0.32 & 0.00 & 1.00 & 0.00 & 1.12 & 0.00 & 0.00 & 0.37 & 0.00 & 0.27 & 0.00 \\
\hline Elphidiella artifex (Serova, 1955) & 0.00 & 0.00 & 0.00 & 0.00 & 0.00 & 0.00 & 0.00 & 0.00 & 0.00 & 0.00 & 0.00 & 0.00 & 0.00 & 0.00 & 0.00 & 1.34 & 0.00 \\
\hline Elphidiella minuta (Reuss, 1850) & 1.88 & 0.00 & 0.00 & 0.29 & 0.00 & 0.28 & 0.00 & 0.00 & 0.00 & 0.00 & 0.00 & 0.00 & 0.00 & 0.00 & 0.00 & 0.00 & 0.00 \\
\hline Elphidium aculeatum (d'Orbigny, 1846) & 1.88 & 1.66 & 0.30 & 0.00 & 0.00 & 0.00 & 0.00 & 0.00 & 0.00 & 0.00 & 0.00 & 0.00 & 0.00 & 0.00 & 0.00 & 19.79 & 0.00 \\
\hline Elphidium cf. fichtelianum (d'Orbigny, 1846) & 0.00 & 0.00 & 0.00 & 0.00 & 0.00 & 0.00 & 0.00 & 0.00 & 0.00 & 0.00 & 0.00 & 0.00 & 0.00 & 0.00 & 5.36 & 1.07 & 0.00 \\
\hline Elphidium cf. grilli Papp, 1963 & 0.00 & 0.00 & 0.00 & 0.00 & 0.00 & 0.00 & 0.00 & 0.00 & 0.00 & 0.00 & 0.00 & 0.00 & 0.00 & 0.00 & 1.34 & 0.00 & 0.00 \\
\hline Elphidium crispum (Linnaeus, 1758) & 0.00 & 0.00 & 0.00 & 0.00 & 0.00 & 0.00 & 0.00 & 0.00 & 0.00 & 0.00 & 0.00 & 0.00 & 0.00 & 0.00 & 0.27 & 0.00 & 0.00 \\
\hline Elphidium hauerinum (d'Orbigny, 1846) & 60.63 & 3.73 & 1.81 & 9.04 & 4.35 & 0.00 & 0.00 & 13.71 & 25.91 & 2.26 & 10.39 & 0.00 & 2.89 & 0.00 & 0.00 & 7.75 & 18.42 \\
\hline Elphidium josephinum (d'Orbigny, 1846) & 0.00 & 0.00 & 0.00 & 0.00 & 0.00 & 0.00 & 0.00 & 0.00 & 0.00 & 0.00 & 0.00 & 0.00 & 0.00 & 0.00 & 0.00 & 0.27 & 0.00 \\
\hline Elphidium sp. & 0.00 & 0.00 & 0.00 & 0.00 & 0.00 & 0.00 & 0.00 & 1.87 & 0.00 & 0.00 & 0.00 & 0.00 & 0.00 & 0.00 & 0.27 & 9.89 & 0.00 \\
\hline Fissurina sp. & 0.00 & 0.00 & 0.00 & 0.00 & 0.00 & 0.00 & 0.00 & 0.00 & 0.00 & 0.00 & 0.00 & 0.00 & 0.00 & 0.00 & 0.00 & 0.27 & 0.00 \\
\hline Fursenkoina acuta (d'Orbigny, 1846) & 0.31 & 0.00 & 0.00 & 0.00 & 0.00 & 0.00 & 0.00 & 0.00 & 0.00 & 0.00 & 0.00 & 0.00 & 0.00 & 0.37 & 0.00 & 0.00 & 0.00 \\
\hline Globocassidulina oblonga (Reuss, 1850) & 0.00 & 0.00 & 0.00 & 0.00 & 0.00 & 2.80 & 0.00 & 0.00 & 0.00 & 0.00 & 0.00 & 0.00 & 0.00 & 0.37 & 0.00 & 0.00 & 0.00 \\
\hline Gyrodinoides sp. & 0.00 & 0.00 & 0.00 & 0.00 & 0.00 & 0.00 & 0.00 & 0.00 & 0.00 & 0.00 & 0.00 & 0.00 & 0.00 & 0.00 & 0.00 & 0.00 & 0.00 \\
\hline hyalin indet. & 0.00 & 0.00 & 0.00 & 0.00 & 0.00 & 0.00 & 0.00 & 0.00 & 0.00 & 0.00 & 0.00 & 0.00 & 0.00 & 0.00 & 0.00 & 4.55 & 0.00 \\
\hline Cibicidoides lobatulus Walker \& Jacob, 1798 & 0.00 & 0.00 & 0.00 & 0.00 & 1.74 & 0.00 & 0.00 & 0.00 & 0.00 & 0.00 & 0.00 & 0.00 & 0.00 & 0.00 & 0.00 & 0.00 & 0.00 \\
\hline Islandiella punctata (Reuss, 1850) & 0.00 & 0.00 & 0.00 & 0.00 & 0.00 & 0.00 & 0.00 & 0.00 & 0.00 & 0.00 & 0.00 & 0.00 & 0.00 & 0.37 & 0.00 & 0.00 & 0.00 \\
\hline Melonis pompiloides (Fichtel \& Moll, 1798) & 0.00 & 0.00 & 0.00 & 0.00 & 0.00 & 0.00 & 0.32 & 0.00 & 0.00 & 0.00 & 0.00 & 0.00 & 0.00 & 0.00 & 1.34 & 0.27 & 0.00 \\
\hline Melonis sp. & 0.00 & 0.00 & 0.00 & 0.00 & 0.00 & 0.00 & 0.00 & 0.00 & 0.00 & 0.00 & 0.00 & 0.00 & 0.00 & 0.37 & 0.27 & 0.00 & 0.00 \\
\hline Millilolidae indet. & 0.00 & 0.00 & 0.00 & 0.00 & 0.00 & 0.00 & 0.00 & 0.00 & 0.00 & 0.00 & 0.00 & 0.00 & 0.00 & 2.21 & 0.00 & 3.48 & 0.00 \\
\hline Neoeponides cf. schreibersi (d'Orbigny, 1846) & 0.00 & 0.00 & 0.00 & 0.00 & 0.00 & 0.00 & 0.00 & 0.00 & 0.00 & 0.00 & 0.00 & 0.00 & 0.00 & 0.74 & 0.00 & 0.00 & 0.00 \\
\hline Nonion bogdanowicz i Voloshinova, 1952 & 0.00 & 0.00 & 0.00 & 0.00 & 0.00 & 0.00 & 0.00 & 0.00 & 0.00 & 0.00 & 0.00 & 0.00 & 0.00 & 1.10 & 0.00 & 0.00 & 0.00 \\
\hline Nonion commune (d'Orbigny, 1846) & 0.63 & 0.00 & 0.00 & 0.00 & 0.00 & 0.00 & 1.59 & 0.00 & 0.00 & 0.00 & 0.00 & 0.00 & 0.00 & 0.00 & 0.27 & 1.60 & 2.63 \\
\hline Nonion sp. & 0.31 & 0.00 & 2.71 & 0.87 & 15.07 & 5.60 & 0.00 & 12.77 & 7.97 & 11.56 & 17.98 & 4.58 & 3.86 & 0.00 & 0.00 & 1.07 & 0.00 \\
\hline Nonion tumidulus Pishanova, 1960 & 0.00 & 0.00 & 0.00 & 0.00 & 0.00 & 0.00 & 0.00 & 0.00 & 0.00 & 0.00 & 0.00 & 0.00 & 0.00 & 1.10 & 0.00 & 0.00 & 0.00 \\
\hline Oolina sp. & 0.00 & 0.00 & 0.00 & 0.00 & 0.00 & 0.00 & 0.00 & 0.00 & 0.00 & 0.00 & 0.00 & 0.00 & 0.00 & 0.37 & 0.00 & 0.00 & 0.00 \\
\hline Plankton indet. & 0.00 & 0.00 & 0.00 & 0.00 & 0.29 & 0.00 & 0.00 & 0.00 & 1.00 & 0.00 & 0.00 & 0.00 & 0.00 & 0.00 & 0.00 & 0.00 & 0.00 \\
\hline Porosononion granosum (d'Orbigny, 1846) & 24.38 & 91.70 & 92.77 & 88.34 & 77.10 & 43.42 & 83.44 & 71.65 & 44.19 & 85.68 & 64.33 & 73.79 & 60.77 & 67.65 & 88.47 & 42.51 & 78.95 \\
\hline Praeglobobulimina pupoides (d'Orbigny, 1846) & 0.00 & 0.00 & 0.00 & 0.00 & 0.00 & 0.00 & 0.00 & 0.00 & 0.00 & 0.00 & 0.00 & 0.00 & 0.00 & 0.37 & 0.00 & 0.00 & 0.00 \\
\hline Praeglobobulimina sp. & 0.00 & 0.00 & 0.00 & 0.00 & 0.00 & 0.00 & 0.00 & 0.00 & 0.00 & 0.00 & 0.00 & 0.00 & 0.00 & 1.10 & 0.00 & 0.00 & 0.00 \\
\hline Pseudotriloculina consobrina (d'Orbigny, 1846) & 7.50 & 0.00 & 0.60 & 0.00 & 0.00 & 2.52 & 0.32 & 0.00 & 0.00 & 0.00 & 0.00 & 1.53 & 8.04 & 0.00 & 0.00 & 0.27 & 0.00 \\
\hline Rosalina sp. & 0.00 & 0.00 & 0.00 & 0.00 & 0.00 & 0.00 & 0.00 & 0.00 & 0.00 & 0.00 & 0.00 & 0.00 & 0.00 & 0.00 & 0.00 & 0.27 & 0.00 \\
\hline Sigmoilopsis sp. & 0.00 & 0.00 & 0.00 & 0.00 & 0.00 & 0.00 & 0.00 & 0.00 & 0.00 & 0.00 & 0.00 & 0.00 & 0.00 & 0.37 & 0.00 & 0.00 & 0.00 \\
\hline Spirolina austriaca d'Orbigny, 1846 & 0.00 & 0.00 & 0.00 & 0.29 & 0.00 & 0.00 & 0.00 & 0.00 & 0.00 & 0.00 & 0.00 & 0.00 & 0.00 & 0.37 & 0.00 & 0.00 & 0.00 \\
\hline Stilostomella sp. & 0.00 & 0.00 & 0.00 & 0.00 & 0.00 & 0.00 & 0.00 & 0.00 & 0.00 & 0.00 & 0.00 & 0.00 & 0.00 & 0.00 & 0.00 & 0.27 & 0.00 \\
\hline Triloculina sp. & 0.00 & 0.00 & 0.00 & 0.00 & 0.00 & 0.28 & 0.00 & 0.00 & 0.00 & 0.00 & 0.00 & 0.00 & 0.00 & 0.37 & 0.00 & 0.27 & 0.00 \\
\hline Valvulineria sp. & 0.00 & 0.00 & 0.00 & 0.00 & 0.00 & 0.00 & 0.00 & 0.00 & 0.00 & 0.00 & 0.00 & 0.00 & 0.00 & 0.00 & 0.00 & 0.00 & 0.00 \\
\hline Varidentella sp. & 0.00 & 0.00 & 0.00 & 0.00 & 0.00 & 0.00 & 0.00 & 0.00 & 0.00 & 0.00 & 0.00 & 0.00 & 0.00 & 0.00 & 0.00 & 1.87 & 0.00 \\
\hline
\end{tabular}

Appendix 1: Quantitative data of the foraminiferal assemblages (percentage per sample) from RKB 5300 and RKB 7260. 


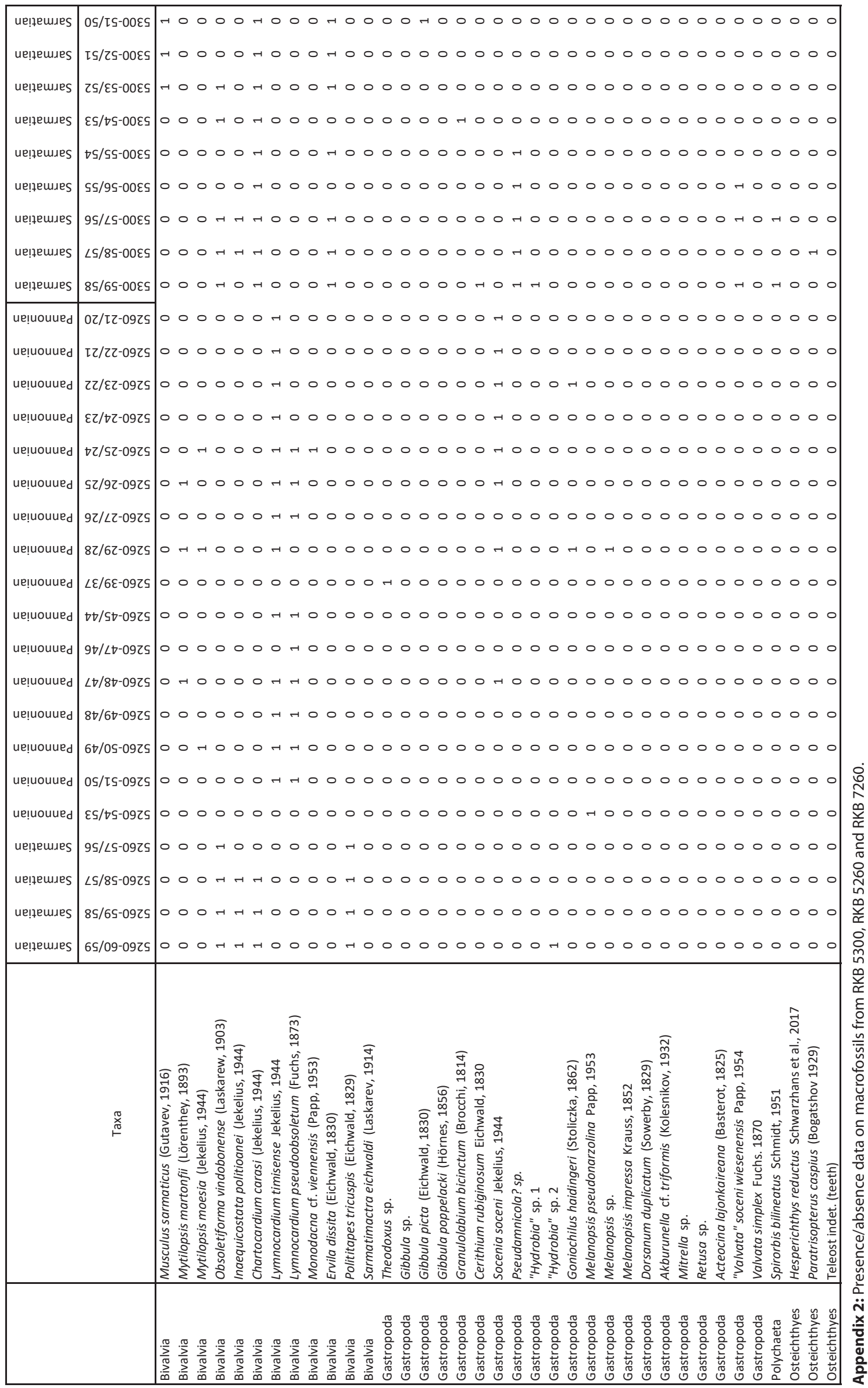




\begin{tabular}{|c|c|c|c|c|c|c|c|c|}
\hline & & 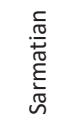 & 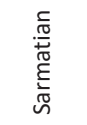 & 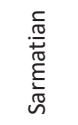 & 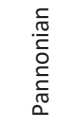 & 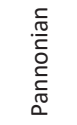 & 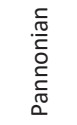 & 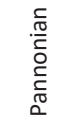 \\
\hline & Taxa & 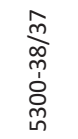 & 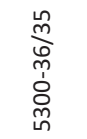 & $\begin{array}{l}\stackrel{m}{m} \\
\stackrel{m}{m} \\
\stackrel{d}{\delta} \\
\text { nn }\end{array}$ & $\begin{array}{l}\stackrel{\infty}{N} \\
\text { స్ } \\
\text { రి } \\
\text { గn }\end{array}$ & 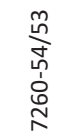 & 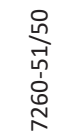 & 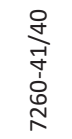 \\
\hline Cupressaceae & Taxioideae & 11.60 & 16.30 & 13.89 & 1.88 & 4.78 & 4.15 & 1.04 \\
\hline Pinaceae & Abies & 4.56 & 8.70 & 11.11 & 5.52 & 5.26 & 5.95 & 7.77 \\
\hline Pinaceae & Cathaya & 10.46 & 8.70 & 2.78 & 23.34 & 20.10 & 7.18 & 13.82 \\
\hline Pinaceae & Picea & 3.42 & 2.17 & 2.78 & 3.76 & 5.50 & 3.48 & 5.70 \\
\hline Pinaceae & Sciadopitys & 0.00 & 0.00 & 0.00 & 0.25 & 0.36 & 0.00 & 0.00 \\
\hline Pinaceae & Tsuga & 3.42 & 17.39 & 11.11 & 10.66 & 9.09 & 6.62 & 9.67 \\
\hline Pinaceae & gen_indet & 6.08 & 3.26 & 0.00 & 31.49 & 16.63 & 45.12 & 53.37 \\
\hline Altingiaceae & Liquidambar & 2.09 & 0.00 & 0.00 & 0.50 & 0.48 & 0.56 & 0.00 \\
\hline Amaranthaceae & Chenopodioideae & 0.19 & 0.00 & 0.00 & 0.00 & 0.24 & 0.00 & 0.00 \\
\hline Anacardiaceae & Rhus & 0.57 & 0.00 & 0.00 & 0.00 & 0.00 & 0.00 & 0.00 \\
\hline Araliaceae & gen_indet & 0.38 & 0.00 & 0.00 & 0.00 & 0.12 & 0.11 & 0.00 \\
\hline Arecaceae & gen_indet & 1.14 & 0.00 & 0.00 & 0.25 & 0.24 & 0.34 & 0.00 \\
\hline Betulaceae & Alnus & 0.76 & 0.00 & 0.00 & 0.13 & 0.00 & 0.00 & 0.00 \\
\hline Betulaceae & Betula & 0.57 & 0.00 & 0.00 & 0.13 & 0.24 & 0.00 & 0.00 \\
\hline Betulaceae & Carpinus & 1.71 & 0.00 & 0.00 & 0.25 & 0.36 & 0.79 & 0.17 \\
\hline Betulaceae & Corylus & 0.38 & 0.00 & 0.00 & 0.00 & 0.00 & 0.00 & 0.00 \\
\hline Cannabaceae & Celtis & 0.38 & 0.00 & 2.78 & 0.00 & 0.24 & 0.11 & 0.00 \\
\hline Cornaceae & Nyssa & 0.00 & 0.00 & 2.78 & 0.13 & 0.00 & 0.22 & 0.35 \\
\hline Cyperaceae & gen_indet & 0.00 & 0.00 & 0.00 & 0.00 & 0.24 & 0.00 & 0.00 \\
\hline Elaeagnaceae & Elaeagnus & 0.00 & 0.00 & 0.00 & 0.13 & 0.00 & 0.00 & 0.00 \\
\hline Ephedraceae & Ephedra & 0.19 & 0.00 & 0.00 & 0.00 & 0.00 & 0.00 & 0.00 \\
\hline Ericaceae & gen_indet & 0.38 & 3.26 & 0.00 & 0.00 & 0.12 & 0.00 & 0.00 \\
\hline Fagaceae & Fagus & 6.46 & 2.17 & 0.00 & 3.26 & 6.34 & 4.83 & 2.59 \\
\hline Fagaceae & Quercus & 10.08 & 4.35 & 11.11 & 1.88 & 2.99 & 3.59 & 1.55 \\
\hline Hamameliaceae & gen_indet & 0.76 & 0.00 & 0.00 & 0.00 & 0.48 & 0.79 & 0.00 \\
\hline Juglandaceae & Carya & 3.99 & 8.70 & 8.33 & 4.64 & 7.42 & 6.17 & 1.21 \\
\hline Juglandaceae & Engelhardia & 2.47 & 1.09 & 0.00 & 0.13 & 0.36 & 0.90 & 0.17 \\
\hline Juglandaceae & Juglans & 1.33 & 0.00 & 0.00 & 1.25 & 2.15 & 1.01 & 0.00 \\
\hline Juglandaceae & Platycarya & 0.19 & 0.00 & 2.78 & 0.00 & 0.00 & 0.11 & 0.00 \\
\hline Juglandaceae & Pterocarya & 0.57 & 0.00 & 0.00 & 0.38 & 0.48 & 0.34 & 0.00 \\
\hline Juglandaceae & gen_indet & 0.00 & 0.00 & 0.00 & 0.00 & 0.48 & 0.00 & 0.00 \\
\hline Malvaceae & Reevesia & 0.00 & 0.00 & 0.00 & 0.00 & 0.12 & 0.00 & 0.00 \\
\hline Malvaceae & Tilia & 0.38 & 1.09 & 0.00 & 1.51 & 1.79 & 0.79 & 0.00 \\
\hline Myrtaceae & gen_indet & 0.76 & 0.00 & 0.00 & 0.00 & 0.00 & 0.00 & 0.00 \\
\hline Oleaceae & Olea & 0.19 & 0.00 & 0.00 & 0.00 & 0.00 & 0.00 & 0.00 \\
\hline Oleaceae & gen_indet & 0.19 & 0.00 & 0.00 & 0.00 & 0.24 & 0.00 & 0.00 \\
\hline Poaceae & gen_indet & 11.03 & 11.96 & 30.56 & 6.02 & 6.22 & 2.69 & 2.25 \\
\hline Rhamnaceae & gen_indet & 0.00 & 0.00 & 0.00 & 0.00 & 0.24 & 0.00 & 0.00 \\
\hline Rosaceae & gen_indet & 0.38 & 0.00 & 0.00 & 0.13 & 0.36 & 0.22 & 0.00 \\
\hline Rutaceae & Zanthoxylum & 0.00 & 0.00 & 0.00 & 0.00 & 0.24 & 0.00 & 0.00 \\
\hline Salicaceae & Salix & 0.19 & 0.00 & 0.00 & 0.00 & 0.00 & 0.00 & 0.00 \\
\hline Sapotaceae & gen_indet & 0.76 & 0.00 & 0.00 & 0.00 & 0.00 & 0.00 & 0.00 \\
\hline Symplpcaceae & Symplocos & 0.00 & 0.00 & 0.00 & 0.00 & 0.24 & 0.00 & 0.00 \\
\hline Thyphaceae & Sparganium & 0.00 & 0.00 & 0.00 & 0.63 & 0.00 & 0.00 & 0.00 \\
\hline Ulmaceae & Ulmus & 8.17 & 6.52 & 0.00 & 1.51 & 2.99 & 2.69 & 0.17 \\
\hline Ulmaceae & Zelkova & 0.76 & 1.09 & 0.00 & 0.25 & 0.24 & 0.34 & 0.00 \\
\hline Ulmaceae & gen_indet & 0.57 & 0.00 & 0.00 & 0.00 & 0.72 & 0.11 & 0.00 \\
\hline Vitaceae & Parthenocissus & 0.57 & 0.00 & 0.00 & 0.00 & 1.20 & 0.34 & 0.00 \\
\hline Vitaceae & gen_indet & 0.57 & 3.26 & 0.00 & 0.00 & 0.60 & 0.45 & 0.17 \\
\hline morpho-taxon & Fupingopollenites wackersdorfensis & 1.33 & 0.00 & 0.00 & 0.00 & 0.12 & 0.00 & 0.00 \\
\hline Pinaceae & Pinus & 57.55 & 84.97 & 87.92 & 63.31 & 61.97 & 35.95 & 38.01 \\
\hline Pinaceae & gen_indet & 2.58 & 0.49 & 0.00 & 11.56 & 6.32 & 28.90 & 33.08 \\
\hline Pinaceae_all & Pinaceae_all & 69.41 & 93.46 & 92.95 & 90.84 & 83.62 & 79.73 & 94.00 \\
\hline pollen & & 80.72 & 88.70 & 90.30 & 92.54 & 93.89 & 93.89 & 96.87 \\
\hline spores & & 2.41 & 0.14 & 0.00 & 1.11 & 0.85 & 0.85 & 0.35 \\
\hline fungi & & 1.43 & 0.00 & 0.00 & 1.15 & 1.84 & 1.84 & 1.04 \\
\hline dinoflagellates & & 15.44 & 11.16 & 9.70 & 5.20 & 3.42 & 3.42 & 1.74 \\
\hline
\end{tabular}

Appendix 3: Percentages calculated for pollen and spore assemblages (excluding Pinus) of the cores RKB 5300 and RKB 7260 . Pinus percentages are based on the total counts. Dinoflagellate and fungi abundance per sample are given in the lower part of the table. 


\begin{tabular}{|c|c|c|c|c|c|c|c|c|c|c|c|c|c|c|c|c|c|c|c|c|c|c|c|c|c|c|c|}
\hline \multirow{2}{*}{\begin{tabular}{|l} 
Taxa \\
Tax
\end{tabular}} & 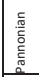 & & 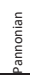 & $\begin{array}{l}\frac{5}{2} \\
\frac{c}{2}\end{array}$ & 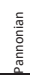 & 悹 & 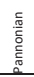 & 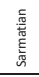 & 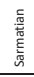 & 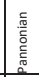 & 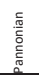 & 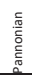 & 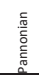 & 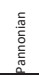 & 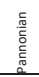 & $\frac{2}{5}$ & 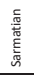 & 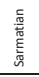 & 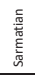 & 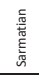 & 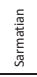 & 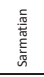 & 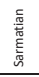 & 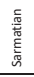 & 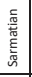 & & \\
\hline & 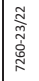 & 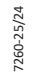 & 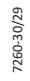 & 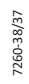 & 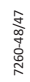 & 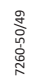 & 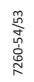 & $\begin{array}{l}\hat{n} \\
\infty \\
0 \\
0 \\
0 \\
\end{array}$ & 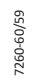 & 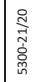 & 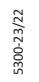 & 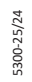 & 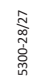 & 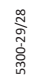 & $\begin{array}{l}\text { શิ } \\
\text { Oे } \\
\text { Oें }\end{array}$ & 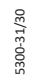 & 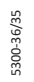 & 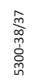 & 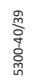 & 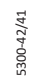 & 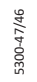 & 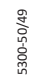 & 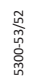 & 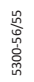 & 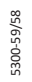 & stratigraphic range & ecology \\
\hline Amnicythere cf. monotuberculata (Sokač, 1972) & \begin{tabular}{|l|}
21 \\
\end{tabular} & 0 & 0 & 0 & 0 & 0 & 0 & 0 & 0 & 0 & 0 & 0 & 2 & 1 & 3 & 0 & 0 & 0 & 0 & 0 & 0 & 0 & 0 & 0 & 0 & ?A-D [1] & see A. tenuis \\
\hline Amnicythere cf. polymorpha (Olteanu, 1989) & 0 & 0 & 0 & 0 & 0 & 0 & 0 & 0 & 0 & 0 & 0 & 0 & 0 & 0 & 10 & 0 & 0 & 0 & 0 & 0 & 0 & 0 & 0 & 0 & 0 & ?E to Dacian $[2,3]$ & see A. tenuis \\
\hline Amnicythere tenuis (Reuss, 1850) & 0 & 0 & 0 & 0 & 0 & 0 & 0 & 0 & 0 & 0 & 0 & 0 & 21 & 0 & 0 & 3 & 0 & 0 & 1 & 0 & 4 & 3 & 7 & 2 & 0 & Sar. to $A-E[4,5,6,7]$ & litt.-sublitt,, mesoh.-freshw. $[3,7]$ \\
\hline Amplocypris sincera Zalányi, 1944 & 25 & 3 & 0 & 0 & 3 & 1 & 0 & 0 & 0 & 4 & 5 & 5 & 2 & 0 & 2 & 0 & 0 & 0 & 0 & 0 & 0 & 0 & 0 & 0 & 0 & A-D, esp. B-C $[8,1]$ & litt., mesoh. [11] \\
\hline Aurila notata (Reuss, 1850) & 0 & 0 & 0 & 0 & 0 & 0 & 0 & 34 & 1 & 0 & 0 & 0 & 0 & 0 & 0 & 0 & 1 & 1 & 0 & 0 & 0 & 0 & 1 & 0 & 0 & U.Sar. $[4,5,6]$ & litt-m.sublitt, mesoh.hyperh., euryh. $[4,10]$ \\
\hline Callistocythere egregia (Méhes, 1908) & 0 & 0 & 0 & 0 & 0 & 2 & 0 & 0 & 0 & 0 & 0 & 0 & 0 & 0 & 0 & 0 & 0 & 0 & 1 & 0 & 0 & 2 & 0 & 0 & 0 & Sar. to B-C $[4,6,8]$ & litt-m.sublitt., marine-mesoh. [10] \\
\hline Candona sp. & 7 & 4 & 0 & 0 & 0 & 0 & 0 & 0 & 0 & 0 & 0 & 2 & 0 & 50 & 0 & 1 & 0 & 0 & 0 & 0 & 0 & 0 & 0 & 0 & 0 & & |itt.-sublitt, freshw.-mesoh. [12] \\
\hline Cnestocythere sp. & 0 & 0 & 0 & 0 & 0 & 0 & 0 & 0 & 0 & 0 & 0 & 0 & 0 & 0 & 0 & 0 & 0 & 0 & 0 & 0 & 0 & 0 & 0 & 0 & 3 & to U.Sar. $[4,6]$ & litt-sublitt, marine-?polyh. [10] \\
\hline Cyamocytheridea leptostigma (Reuss, 1850) & 0 & 0 & 0 & 0 & 0 & 0 & 0 & 0 & 0 & 0 & 0 & 0 & 0 & 0 & 0 & 0 & 0 & 0 & 0 & 15 & 0 & 0 & 0 & 1 & 3 & Bad. to Sar., esp. U.Sar. $[4,5,6]$ & litt-m.m.sublitt,, marine-polyh. [12, 13] \\
\hline Cypria reniformis (Héj.jas, 1892) & 16 & 0 & 0 & 0 & 0 & 0 & 0 & 0 & 0 & 0 & 0 & 0 & 0 & 0 & 0 & 0 & 0 & 0 & 0 & 0 & 0 & 0 & 0 & 0 & 0 & A-E $[8]$ & |litt., freshw.-mesoh., phytal [12] \\
\hline Cyprideis tuberculata (Méhes, 1908) & 9 & 7 & 20 & 0 & 0 & 4 & 1 & 0 & 0 & 0 & 0 & 0 & 1 & 0 & 0 & 0 & 0 & 0 & 0 & 0 & 0 & 0 & 0 & 0 & 0 & $A-C$, esp. $B[1,8,9]$ & litt., freshw.-hyperh., euryh. [3, 11] \\
\hline Hemicyprideis dacica (Héj.jas, 1894) & 0 & 0 & 0 & 0 & 0 & 0 & 0 & 0 & 0 & 0 & 0 & 0 & 0 & 0 & 0 & 0 & 0 & 0 & 0 & 0 & 0 & 0 & 0 & 0 & 1 & to U.Sar. [5, & see C. tuberculata [14] \\
\hline Hemicytheria hungarica (Méhes, 1908) & 17 & 6 & 0 & 0 & 0 & 8 & 13 & 0 & 0 & 0 & 0 & 0 & 16 & 0 & 3 & 5 & 0 & 0 & 0 & 0 & 0 & 0 & 0 & 0 & 0 & U.Sar. to A-B, esp. B $[1,5,8]$ & see H. omphalodes \\
\hline Hemicytheria omphalodes (Reuss, 1850) & 15 & 3 & 0 & 0 & 0 & 8 & 2 & 0 & 0 & 0 & 0 & 0 & 12 & 0 & 0 & 4 & 0 & 0 & 0 & 1 & 0 & 0 & 0 & 0 & 11 & U.Bad. to A-B, esp. U.Sar. $[4,5,10]$ & litt.-m.sublitt., oligoh.-polyh. [10] \\
\hline Herpetocyprella auriculata (Reuss, 1850) & 0 & 0 & 2 & 3 & 0 & 0 & 2 & 0 & 0 & 0 & 0 & 0 & 0 & 0 & 2 & 0 & 0 & 0 & 0 & 0 & 0 & 0 & 0 & 0 & 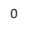 & A-C (E), esp & litt., mesoh.-freshw. $[3,11]$ \\
\hline Loxoconcha cf. irregularis (Olteanu, 1986) & 7 & 0 & 0 & 0 & 1 & 0 & 0 & 0 & 0 & 0 & 0 & 0 & 8 & 0 & 0 & 1 & 0 & 0 & 0 & 0 & 0 & 0 & 0 & 0 & 0 & PC-D [2] & see L. kochi \\
\hline Loxoconcha kochi (Méhes, 1908) & 1 & 0 & 0 & 0 & 0 & 0 & 0 & 0 & 0 & 0 & 0 & 0 & 0 & 0 & 0 & 0 & 0 & 0 & 0 & 0 & 0 & 0 & 0 & 0 & 0 & U.Bad. to A-C $[4,6,10]$ & litt.-m.sublitt., mesoh.-marine [10] \\
\hline Loxoconcha mülleri (Méhes, 1908) & 0 & 0 & 0 & 0 & 0 & 0 & 0 & 0 & 0 & 0 & 0 & 0 & 10 & 0 & 0 & 0 & 0 & 0 & 0 & 0 & 0 & 0 & 0 & 0 & 0 & A-E [8] & see $L$. kochi \\
\hline Loxoconcha sp. & 17 & 0 & 0 & 0 & 0 & 0 & 0 & 0 & 0 & 0 & 0 & 0 & 0 & 0 & 0 & 0 & 0 & 0 & 0 & 0 & 0 & 0 & 0 & 0 & 0 & & see $L$. kochi \\
\hline Loxocorniculina hodonica (Pokorný, 1952) & 0 & 0 & 0 & 0 & 0 & 0 & 0 & 0 & 0 & 0 & 0 & 0 & 8 & 0 & 12 & 0 & 0 & 0 & 0 & 0 & 0 & 0 & 0 & 0 & 0 & $A-E[1, \varepsilon$ & see L. kochi \\
\hline Xestoleberis cf. fuscata Schneider, 1953 & 0 & 0 & 0 & 0 & 0 & 0 & 0 & 0 & 4 & 0 & 0 & 0 & 0 & 0 & 0 & 0 & 0 & 0 & 0 & 2 & 1 & 0 & 1 & 0 & 0 & Bad. to Sar. [6] & |litt-m.sublitt,, marine-mesoh., phytal [10] \\
\hline & 135 & 23 & 22 & 3 & 4 & 23 & 18 & 34 & 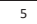 & 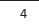 & 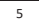 & & 80 & 31 & 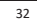 & 14 & 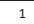 & & 2 & & & & & & & & \\
\hline
\end{tabular}

Appendix 4: Occurrences and stratigraphic range of ostracods in RKB 5300 and RKB 7260. Bad. $=$ Badenian, Sar. $=$ Sarmatian, U. = upper; esp. $=$ especially; upper case letters $=$ zones of Papp (1951); lit. = littoral, sublitt. $=$ sublittoral zone, m.sublitt. $=$ medium-deep sublittoral zone; freshw. $=$ freshwater, oligoh . $=$ oligohaline, mesoh. $=$ mesohaline, polyh. $=$ polyhaline, hyperh.$=$ hyperhaline, euryh.$=$ euryhaline; square brackets = references: 1: Krstić, 1985, 2: Olteanu, 1989, 3: Cziczer et al., 2009, 4: Cernajsek, 1974, 5: Jiříček, 1974, 6: Tóth, 2008, 7: Namiotko et al., 2012, 8: Jiř́ček, 1985, 9: Kollmann, 1960, 10: Gross, 2006, 11: Gross, 2004, 12: Morkhoven, 1963, 13: Pirkenseer and Berger, 2011, 14: Malz, 1971.

Malz, H., 1971. A paleoecological review of the Chattian/ Aquitainian boundary in the Mainz Basin by means of ostracoda. In: H.J. Oertli (ed.): Paléoécologie des Ostracodes. Bulletin du Centre de Recherches, Supplement 5. Pau-Societe Nationale des Petroles d'Aquitaine, Pau, pp. 515-522.

Morkhoven van, F.P.C.M., 1963. Post-Palaeozoic Ostracoda, their Morphology, Taxonomy, and Economic use. Volume 2, Generic descriptions. Elsevier, Amsterdam/London/New York, 478 pp. https://doi. org/10.1086/404561
Namiotko, T., Danielopol, D.L., Belmecheri, S., Gross, M. and Grafenstein von, U., 2012. On the Leptocytheridae Ostracods of the long-lived Lake Ohrid: a reappraisal of their taxonomic assignment and biogeographic origin. International Review of Hydrobiology, 97/4, 356-374. https://doi.org/10.1002/iroh.201211496

Pirkenseer, C. and Berger, J.P., 2011. Paleogene Ostracoda from the southern Upper Rhine Graben: Taxonomy, palaeoecology and palaeobiogeography. Palaeontographica, A, 295, 1-152. https://doi.org/10.1127/ pala/295/2011/1 